\title{
The role of cryptotephra in refining the chronology of Late Pleistocene human evolution and cultural change in North Africa
}

\author{
Barton, R.N.E. ${ }^{1}$, Lane, C.S..$^{2,3}$, Albert, P.G. ${ }^{3,4}$, White, D. ${ }^{5}$, Collcutt, S.N. ${ }^{6}$, Bouzouggar, A. ${ }^{7,8}$, \\ Ditchfield, P. ${ }^{3}$, Farr, L. ${ }^{9}$, Oh, A. ${ }^{3,10}$, Ottolini, L. ${ }^{11}$, Smith, V.C. ${ }^{3}$, Van Peer, P. ${ }^{12}$, Kindermann, K. ${ }^{13}$.
}

1. Institute for Archaeology, University of Oxford, 36 Beaumont Street, Oxford OX1 2PG, UK

2. Geography, School of Environment, Education and Development, University of Manchester, Oxford Road, Manchester, M13 9PL, UK

3. Research Laboratory for Archaeology and the History of Art, University of Oxford, Dyson Perrins Building, South Parks Road, Oxford OX1 3QY, UK

4. Department of Geography, College of Science, Swansea University, Singleton Park, Swansea SA2 8PP, UK

5. Archaeology, University of Southampton, Southampton SO17 1BF, UK

6. Oxford Archaeological Associates Ltd, Oxford OX4 1LH, UK

7. Institut National des Sciences de l'Archéologie et du Patrimoine, Rabat-Instituts, 10000 Rabat, Morocco

8. Department of Human Evolution, Max Planck Institute for Evolutionary Anthropology, D-04103 Leipzig, Germany

9. McDonald Institute for Archaeological Research, University of Cambridge, Cambridge CB2 3ER, UK

10. Department of Earth \& Atmospheric Sciences, University of Alberta, 1-26 ESB, Edmonton, Alberta, T6G 2E3, Canada

11. Consiglio Nazionale delle Ricerche (CNR) - Istituto di Geoscienze e Georisorse (IGG), Unità di Pavia, I-27100 Pavia, Italy

12. Department of Archaeology, Catholic University of Leuven, Belgium

13. Institute of Prehistoric Archaeology, CRC 806 - African Archaeology, University of Cologne, Bernhard-

Feilchenfeld-Straße 11, 50969 Köln, Germany

Corresponding author: R.N.E. Barton. Email: nick.barton@arch.ox.ac.uk

\begin{abstract}
Sites in North Africa hold key information for dating the presence of Homo sapiens and the distribution of Middle Stone Age (MSA), Middle Palaeolithic (MP) and Later Stone Age (LSA) cultural activity in the Late Pleistocene. Here we present new and review recently published tephrochronological evidence for five cave sites in North Africa with long MSA/MP and LSA cultural sequences. Four tephra horizons have been identified at the Haua Fteah (Cyrenaica, Libya). They include cryptotephra evidence for the Campanian Ignimbrite (CI) eruption dating to 39 ka that allows correlation with other Palaeolithic sequences in the eastern Mediterranean and as far north as Russia. Cryptotephra have also been recorded from the Moroccan sites of Taforalt, Rhafas and Dar es-Soltane 1. At Taforalt the geochemical composition suggests a provenance in the Azores, while examples from Sodmein (Egypt) appear to derive from western Anatolia and another unknown source. In these latter examples chemical compositional data from relevant proximal volcanic centres is currently lacking so the identification of tephra in layers of known age and cultural association provides the first reliable age determinations for distal volcanic events and their geographical extent. The future potential for tephrochronological research in North Africa is also discussed.
\end{abstract}


Accepted for publication in Quaternary Science Reviews on 05/09/2014

Keywords

Homo sapiens, tephrochronology, Campanian Ignimbrite (CI), Middle Stone Age (MSA), Middle Palaeolithic (MP), Later Stone Age (LSA), Iberomaurusian.

\section{Introduction}

North Africa is an area of exceptional interest for the study of Homo sapiens in the Late Pleistocene ( 200-10 ka BP). The region contains some of the richest known archaeological and

paleontological collections from caves and rock shelters of this period and yet in comparison to East and South Africa it has received far less scientific attention. This is partly due to the historical focus of research work on sub-Saharan areas of the continent but also to the fact that relatively little of its relevant fossil and cultural material has yet been comprehensively published (Stringer and Barton 2008). North Africa, as with the rest of Africa, also shares the distinction that all of the technological changes and behavioural developments over the past $200 \mathrm{ka} \mathrm{BP}$ appear to have occurred within $H$. sapiens populations. This contrasts markedly with adjacent areas of SW Asia and Europe where the cultural stages of the Middle Palaeolithic and Upper Palaeolithic are attributable to different species, respectively Homo neanderthalensis and H. sapiens (Klein, 2009).

One of the recurrent debates in evolutionary studies concerns the nature and timing of H.sapiens dispersal(s) within Africa and subsequent spread to other areas of the world. In North Africa there are two current hypotheses that share more or less equal prominence. The first suggests that $H$. sapiens was already present in North-West Africa by 200 ka BP (Smith et al., 2007) and these were morphologically similar to East African populations and the first 'modern' humans to leave Africa (Hublin et al., 2012; Harvati and Hublin, 2012). A more conservative view is that archaic forms of $H$. sapiens occupied North Africa and the Levant in this timeframe but they were unrelated to the modern humans that left Africa around 70-60 ka BP (Mellars, 2006; Stringer, 2012). As with arguments on the taxonomic status of early $\mathrm{H}$. sapiens in North Africa, opinion is also divided over the nature of associated lithic technologies and the implications for understanding human behavioural change. Most authors now accept that there is a shift to generalised use of Levallois prepared core technology throughout sub-Saharan and North Africa from 300 ka BP (McBrearty and Brooks, 2000; Barham and Mitchell, 2008; Hopkinson et al., 2013) but there is far less agreement over how regional differences in cultural sub-stages developed and should be described.

In the Maghreb (modern Morocco, Algeria, Tunisia and Western Libya) the Middle Stone Age (MSA) is represented by flake-based industries and variants in which blade-like flakes sometimes feature more prominently. The latter are often associated with distinctive tools such as foliates and 
Accepted for publication in Quaternary Science Reviews on 05/09/2014

stemmed points that are typical of the Aterian (Reygasse, 1919-1920; Caton Thompson, 1946; Tixier, 1959; Bouzouggar and Barton, 2012). The earliest appearance of prepared Levallois cores can be dated to $300 \mathrm{ka}$ at Grotte du Rhinocéros, Morocco (Raynal et al., 2010) while developed prepared core technologies - once described as 'Mousterian' - are known from Djbel Irhoud, Morocco (Hublin et al., 1987) from around 190-160 ka BP and potentially earlier (Geraads et al., 2013). At other sites in Morocco occupying the time range of 150-90 ka BP, such as Ifri n'Ammar, the sequence appears to show alternating MSA Mousterian and Aterian layers (Nami and Moser, 2010), which has been interpreted as evidence that the Aterian was a North African facies of the Mousterian (Richter et al., 2012). However, in the majority of cases where longer sequences are recorded the Aterian is generally stratified above 'Mousterian'-like industries, as exemplified by Contrebandiers Cave (Dibble et al., 2013) and Grotte de Rhafas (Wengler, 1993). The oldest Aterian at these and other sites can be dated from 114 ka BP (Barton et al., 2009; Schwenninger et al., 2010; Jacobs et al., 2012).

In areas outside the Maghreb such as Egypt and Cyrenaica (Eastern Libya) a different MP/MSA sequence can be described (Van Peer, 2004). Dating from $200 \mathrm{ka} \mathrm{BP}$, the oldest variant is known as the Sangoan and contains core-axes and discoidal prepared core technology. It is found in the Middle Nile Valley and further south and may occur in the central Sahara and parts of Tunisia (Van Peer, in press). In Sudan and Egypt, the Sangoan is followed by a Lupemban facies with the addition of lanceolate foliates and volumetric blade production. This appears to give way to developed Levallois flake industries of the Nile Valley Nubian complex (Van Peer and Vermeersch, 2007). From $130 \mathrm{ka}$ BP lithic assemblages in the Western Egypt Desert contain recognisable Aterian components but these are rarer further north in Cyrenaica. At the Haua Fteah in Libya, for example, there is no well defined Aterian material (Reynolds, 2013; Scerri, 2013). Instead there are 'Pre-Aurignacian' levels that include distinct blades and foliate points that look similar to those in the Lupemban/early Nubian Complex. Parallels have been drawn between the Pre-Aurignacian and Nubian assemblages at Taramsa I in Egypt, broadly dated to between 117-88 ka BP (Van Peer, in press). Of interest in the Haua Fteah sequence is the apparent separation of the Pre-Aurignacian from an overlying Levalloiso-Mousterian industry which also contains an associated presence of two fossil mandibles of $H$. sapiens (McBurney, 1967).

A major cultural development concerns the transition from the Middle to the Later Stone Age (LSA). This is a very widespread phenomenon that is recorded in North Africa and throughout much of sub-Saharan Africa and is marked by a change from MSA flake and blade technologies to a more standardised microlithic bladelet production. It is still unclear whether this transition was 
synchronous across broad regions (Mitchell, 2008) and/or whether it developed as a gradual (Villa et al., 2012) or a more punctuated time-transgressive process (Barton et al., 2013). In North Africa from Morocco as far east as Libya the LSA microlithic bladelet industries are often referred to as Iberomaurusian (Lubell, 2001). Several questions have arisen over the chronology of this industry but in Morocco and Algeria its first appearance can be dated to 25-23 ka Cal BP${ }^{1}$, based on new AMS radiocarbon dates (Barton et al., 2013). At the site of Taforalt, Morocco there is a clear break with the underlying MSA, involving a potential gap of around 2600-3880 years (at 95\% confidence interval) (Barton et al., 2013). In Cyrenaica, the MSA-LSA transition is interpreted somewhat differently with the Dabban industry possibly representing an early Upper Palaeolithic technology or a transitional MSA equivalent and dating to around 46-41 ka BP (according to modelled ages in Douka et al., 2014a). The first appearance of the Iberomaurusian (also known as Eastern Oranian) at this site, which directly overlies the Dabban (McBurney, 1967), seems to have been slightly later than in the Maghreb. At the Haua Fteah, this transition has a modelled age of 17.5-16.6 ka BP (Douka et al., 2014a). However, greater clarification is still required over whether the Iberomaurusian developed directly out of the Dabban; in the Maghreb there is currently nothing that fits the Dabban description or that has been found in stratigraphic association with the Iberomaurusian, which suggests independent trajectories for the development of the LSA technologies in each of these areas.

Clearly there are continuing uncertainties over the timing and development of the MSA and LSA in North Africa and its association with $H$. sapiens. As part of the RESET project ${ }^{2}$, we applied the technique of tephrochronology to sites in this region for the first time. The objective of this work was to refine our understanding of the chronology of individual site sequences and use synchronous tie-points to relate cultural developments across the wider region of North Africa and even potentially as far as Europe. The principles of tephrochronology are by now well established (Lowe et al., 2011). Ash, comprised mainly of glass shards (tephra), is ejected from an explosive volcanic eruption and is spread through the atmosphere for sometimes thousands of kilometres. Tephra fallout, from an ash plume or as co-ignimbrite clouds, produce widespread layers that decrease in thickness and shard size with distance from the source. Very often these shards survive at distal sites (that is, sites distant from the volcanic source) only as tiny microscopic elements referred to as cryptotephra. The aim of cryptotephra investigations is to locate widespread tephra isochrons; the target dating event is the time of the volcanic eruption and the assumption is that its deposition into sediments is pene-contemporaneous with the eruptive event. Since the glass shards provide a geochemical signature that is theoretically unique to that eruptive event, their distribution provides a useful synchronous marker that can be traced over geographically extensive areas (see for example, 
Accepted for publication in Quaternary Science Reviews on 05/09/2014

Turney et al., 1998; van den Bogaard and Schmincke, 2002; Lowe et al., 2012). Thus, as well as providing a direct proxy for dating an individual occupation layer, tephra can also be used as a means for independently testing inter-site (as well as within site) correlations over wide regions and at relatively high precision (centennial to decadal timescales).

The aims of the RESET study of sites in North Africa were threefold:

- To locate identifiable tephra and cryptotephra in Middle Stone Age (MSA) and Later Stone Age (LSA) layers and to use this as a correlation tool for linking and synchronizing archaeological and environmental records at widely spaced intervals across North Africa.

- To use these data to examine the implications for theories of modern human dispersals in North Africa and related cultural changes both within the MSA and the transition from the MSA to the LSA in this region.

- To test the relationship between proximal and distal tephra sources so that areas of future potential for chronological studies across North Africa could be identified.

\section{Site selection}

In order to address the aims outlined above we chose a longitudinal study that focused on sites in a broad transect from west to east across North Africa, from the Atlantic and Mediterranean coasts to the Red Sea margin and Levant (Fig. 1). The aim of this selection was to sample sites both relatively close to the well-documented zone of volcanic activity in southern Italy but also to test the proposition that other datable tephra might be detected distally in areas outside the influence of the well-studied Italian sources. In all, eight sites were identified as being suitable for this study: three in Morocco, two in Tunisia and one each in Libya, Egypt and Israel (Fig. 1, Table 1). These represent only a small sub-set of a much larger group of sites that could have been tested. However, in applying strict criteria that included only those sites with long sequences of MSA and LSA layers, that had been the subject of modern excavations and that were accessible for sampling (due to political unrest several countries had to be excluded) our choice of site for this initial study was somewhat restricted.

Our selection of sites was also partly directed by recent research which suggests that sediment records in caves and rock-shelters offer amongst the best opportunities for investigating cryptotephra from widely dispersed eruptions (e.g. Boric et al., 2012; Douka et al., 2014a; Lowe et al., 2012). This is particularly the case where the survival of the microscopic glass shards may be favoured by a combination of allochthonous sedimentation through large cave entrances and reduced erosion and bioturbation (Lane et al., 2014). Cryptotephra deposits are believed to be 
mainly transported into cave or rock shelter sequences along with their host sediments, with only perhaps a small component, in exceptional circumstances, falling out directly into the cave entrance. It is important to consider the influence of taphonomic processes when assessing the value of a tephra layer as an isochronous marker. Aspects such as varying sedimentation rates, distance from the volcanic source and the nature of the intervening terrain, as well as the processes of emplacement (slope-wash, windblow, etc) may impact upon the rate of tephra deposition and burial. For example, colluvial activity may be responsible for introducing tephra into a cave sometime after the actual eruption event. The position of a cryptotephra horizon in a stratigraphic layer may also be affected by re-mobilisation of tephra shards through processes such as compaction, bioturbation or water percolation (Davies et al., 2007; Payne and Gehrels, 2010; Morley and Woodward, 2011). Therefore, demonstrating discrete event horizons within the sediments (i.e., distinct peaks of high concentration glass shards) is critical when identifying the isochron position and where appropriate, depth uncertainty should be built into dating schemes in site age models (Lane et al., 2014). In terms of the sites we selected for cryptotephra investigations, they lie at varied altitudes with openings of different sizes and orientation and with different types and scales of sedimentation. A brief synopsis of each of the sites (taken geographically from west to east) and the sampling procedures adopted is presented in Table 1, which also includes a summary of the progress of the investigations. As can be seen, of the eight sites sampled, no tephra was recovered from Aïn ElGuettar and work on El Akarit and Kebara Cave is still in progress. Therefore, in this paper we present and discuss results from only five of the sampled sites, focussing in particular on Taforalt, Haua Fteah and Sodmein Cave, from which tephra layers were successfully characterised and correlated at least to a source region. Further detail on the dating and stratigraphy of these three sites is given in Section 4 (Results).

\section{Material and methods}

All sites were sampled at 2 or $5 \mathrm{~cm}$ contiguous intervals along single, or multiple overlapping, sample columns, placing samples in sealed bags according to the methods presented in Lane et al. (2014). The sediment samples were then processed in the laboratory using methods described in Blockley et al. (2005), which aim to isolate volcanic glass from its host sediment using the physical properties of the tephra (density and grain size). Initial investigations were carried out at low depth resolution by amalgamation of sub-samples respecting context boundaries (the interval was partly dependent upon the nature and thickness of the archaeological contexts). For sites sampled for cryptotephra at $2 \mathrm{~cm}$ intervals (Dar es-Soltane 1, Taforalt, Rhafas, Aïn El-Guettar, Haua Fteah), this involved in most cases amalgamating 5 individual sub-samples representing a vertical depth of 10 $\mathrm{cm}$, and for those sampled at $5 \mathrm{~cm}$ intervals (Dar es-Soltane 1, Sodmein) admixing 4 sub-samples 
Accepted for publication in Quaternary Science Reviews on 05/09/2014

spanning a vertical depth of $20 \mathrm{~cm}$. If tephra shards were found during low resolution scans the corresponding individual bag samples were then processed to further identify the exact sediment depth containing the cryptotephra layer. Concentrations of volcanic glass shards were calculated after counting from grain mounts under high-powered optical microscopy and are stated as the number of shards per gram of dry sediment $(\mathrm{s} / \mathrm{g})$. Where high concentrations of glass shards were located, these samples were re-examined at $2 \mathrm{~cm}$ resolution to pinpoint more precisely the stratigraphic position of the tephra horizon.

For each tephra layer, glass shards were concentrated and prepared for single grain compositional analysis. Major and minor element compositions were estimated by wavelength-dispersive electron microprobe analysis (WDS-EMPA), using the Jeol JXA8600 microprobe at the Research Laboratory for Archaeology, University of Oxford (operating conditions: 15keV, 6nA, $10 \mu \mathrm{m}$ beam, peak count times 10-60 seconds). The same grain mounts were mapped and used for both EMP and trace element analyses, to facilitate re-location and analysis of individual shards, which allows full quantification of the single grain trace element compositions.

Trace element compositions were analysed by laser ablation inductively coupled plasma mass spectrometry (LA-ICP-MS) using an Agilent 7500ce ICP-MS coupled to a $193 \mathrm{~nm}$ Resonetics ArF eximer laser ablation system with a two-volume ablation cell, in the Department of Earth Sciences, Royal Holloway University of London (Müller et al., 2009). LA-ICP-MS procedures followed the methods of Tomlinson et al. (2010), which are specifically designed for the analysis of fine-grained ash deposits. Analyses utilized a $25 \mu \mathrm{m}$ laser spot size, a repetition rate of $5 \mathrm{~Hz}$ and $40 \mathrm{~s}$ sample and gas blank count times. Quantification used NIST612 as the calibration standard with 29Si as the internal standard. Secondary standard glasses ATHO-G and St/Hs6/80-g from the MPI-DING collection (Jochum et al., 2005; 2006) were run to assess accuracy and reproducibility of analyses. Where grain sizes were insufficient for analysis by LA-ICP-MS, samples were analysed instead by Secondary Ion mass Spectrometry (SIMS) at the CNR- (IGG), Unit of Pavia (Italy). Samples were polished and Pt-coated prior to analyses. Analyses were done with a Cameca IMS $4 \mathrm{f}$ ion microprobe using a 0.5-0.7 nA primary-beam current intensity, under a 5-8 $\mu \mathrm{m}$ spot diameter, -12.5 $\mathrm{kV}$ accelerating voltage and energy filtering of secondary ions (75-125 eV emission energies), using methods similar to those adopted by Ottolini (Schiano et al., 2001; 2004). In order to increase the sensitivity on very small samples $(<10$ micron diameter), experimental methods were optimised by increasing the acquisition times of secondary ion signals. The trace-element concentrations were calculated using the $\mathrm{SiO}_{2}(\mathrm{wt} \%$ ) values obtained from previous EMP analyses performed in the same shards selected for the SIMS investigation. The precision of a single analysis from Poisson 
Accepted for publication in Quaternary Science Reviews on 05/09/2014

counting statistics for the various isotopes detected is on the order of few percent rel. and generally better than $10 \%$ rel. (as $1 \sigma \%$ ) at ppm-tens ppm wt concentration. Two international reference materials were used as primary standards including NIST-SRM 610 and BCR-2G, alongside these two well characterised internal standards (BB and WY1) were analysed during the sample runs. Considering all the errors involved in the SIMS investigation, related both to the reference concentrations assumed for the calibration standards and to the analytical precision of the SIMS data themselves, we can estimate accuracy to be comparable to precision in the range $(1-3 \sigma)$.

\section{Results}

Taking each site in turn, we here present the cryptotephra findings from Dar es-Soltane 1, Taforalt, Rhafas, Haua Fteah and Sodmein Cave. The degree of success was variable between sites, which each posed its own specific challenges (e.g. taphonomy, lack of reference data on regional eruptions). A discussion of the implications of our findings on the potential of cryptotephra as a dating and correlation tool in North African cave sites can be found in Section 5.

\subsection{Dar es-Soltane 1}

Tephra shards were located in six stratigraphic horizons, all mostly in very low concentrations $(<6$ shards / gram dry sediment). One horizon (-18 to $-20 \mathrm{~cm}$; likely to be in sub-unit G4.7) produced shards at concentrations of 11 shards/gds. However, as no specific isochron position could be determined, no geochemical analysis was attempted on this layer.

Given the position of the cave in a broadly westerly airstream, tephra from an Atlantic volcanic source would be likely to reach and deposit tephra in this region. However, whilst the cavity is very close to the surface, with which it connects through a number of large roof apertures, exterior slopes are 'short', such that geomorphological (overland) catchment is small. This situation means that only tephra falling in the immediate area would quickly find its way into the cave, reducing the concentration of air fall tephra which is expected when a larger catchment is available.

The sediments of Dar es-Soltane 1 have also been more or less completely decalcified, with strong signs of concomitant phosphatic and possibly sulphatic mobilisation. These observations suggest that both unusually acidic and unusually alkaline conditions could have developed very locally (and variably through time) in pore water. Such conditions are likely to have resulted in aggressive alteration - possibly even complete destruction - of tephra, effects that would have been stronger the smaller the particles concerned and the lower the silica content of the ash. These conditions may well have contributed to the limited amount of tephra located in the site. A sequence on the NE side 
Accepted for publication in Quaternary Science Reviews on 05/09/2014

of the cave, which has not been decalcified, may offer a location to test whether or not tephra was deposited in the cave and therefore if it has been subsequently weathered from the investigated sediments.

\subsection{Taforalt}

Taforalt has been the subject of long-term cryptotephra investigations, as the cave is well-suited to trapping fine grained material within the low-energy, fine-grained sediments. It is likely that tephra enters the cave not only within a wind-blown component through the large cave opening, but also through avens and fissures in the roof, which are fed from a wide surface catchment to the south. These varied avenues may play a role in prolonging, or delaying, the input of tephra into the site as well as helping to explain the variable distributions of cryptotephra found in different sectors of the excavation. Concentrations of cryptotephra have been found in four main locations: three layers in overlapping columns taken across Sectors 1 and 2 (layers R2, R4 and R16), and one in Sector 8 (layer Y1) (Fig. 2-4). The layers have been named with respect to the context they have been found in and they are each described here in terms of their stratigraphic position, appearance, composition, age and likely correlations (Fig. 5).

\subsubsection{Sectors 1 and 2}

TAF_S1_R2 occurs in powdery sediments of the Upper Laminated Group, less than $10 \mathrm{~cm}$ above TAF_S1_R4 in Sector 1, forming a subtle double peak (Fig. 3). The shard counts are extremely low and variable across the sample columns in Sectors 1 and 2. Radiocarbon dates of $\sim 26,528$ to 24,420 $\mathrm{Cal} \mathrm{BP}$, from layers R3/4 provide some guidance as to the age of the two tephra layers. The third cryptotephra TAF_S2_R16 was identified only in Sector 2, in layer R16 of the Lower Laminated Group sediments (Fig. 2-3) and is constrained by OSL dates to $~ 50 \mathrm{ka} \mathrm{BP}$.

\section{i. TAF_SI_R2}

Glass shards in TAF_S1_R2 appear mostly cuspate, with some shards having open or elongated vesicles. Shards have longest axis lengths of up to $70 \mu \mathrm{m}$. The maximum shard concentration is 36 shards/gram at the base of the layer. In total 23 tephra glass shards from Layer R2 were successfully analysed by WDS-EMP from across Sector 1 and 2 (Table 2) and nine shards using LA-ICP-MS and SIMS (Table 3). The LA-ICP-MS and SIMS data show good agreement, within two standard deviations, across all elements. The data reveals that TAF_S1_R2 has a homogeneous trachytic composition (Fig. 5). 
Accepted for publication in Quaternary Science Reviews on 05/09/2014

Trachytic tephra are extremely common in the North Atlantic and Mediterranean region, therefore Fig. 5 compares the composition of TAF_S1_R2 to data on previously-described widespread tephra layers that occurred between 18-30 ka Cal BP in the circum-Mediterranean region. No compositional match was found with tephra from Southern Italian sources. Contemporary eruptions of Vesuvius are distinct on all elements, whilst trace element composition demonstrates that tephra from the Ischian eruption of Faro di Punta Imperatore, is also distinct (Fig. 5d). Considering the Western Mediterranean location of Taforalt, the limited available data for contemporaneous eruptions of volcanoes on the Azores is also plotted in Fig. 5a and b. The major and minor element composition of TAF_S1_R2 shows a close match to trachytic tephra from Sete Cidades, a volcano on the island of Sao Miguel (Beier et al., 2006). Unfortunately, no trace element compositional data is yet available for Sete Cidades but it does seem likely that the dominant westerly winds in this region could also transport small amounts of volcanic ash to North Africa, even from $2000 \mathrm{~km}$ away. Whilst closer (less than $1500 \mathrm{~km}$ away), a Canaries source can probably be excluded because the various eruptions between 30-10 ka BP are reported as phonolitic in composition (Martí et al., 2008). However, no single grain glass data was found for comparison.

\section{ii.TAF_S1_R4}

Non-vesicular glass shards with either plate-like or bubble-junction morphologies and longest axis lengths of up to $70 \mu \mathrm{m}$, were found in layer R4 in a concentration of 15 shards/gram. Seven EMP analyses were achieved on TAF_S1_R4, revealing a rhyolitic composition (Fig. 5). Of the shards analysed, three of these display low $\mathrm{Na}_{2} \mathrm{O}$ and (possibly inflated $\mathrm{K}_{2} \mathrm{O}$ ) contents, indicating that alkali exchange has likely occurred. No trace element analysis was carried out on this layer. Whilst compositional data is limited, it is apparent that the composition is very similar to that of the much younger TAF_S8_Y1 (section 4.2.4.), suggesting that different eruptions from the same source may have delivered tephra to Taforalt multiple times during the Late Quaternary. The few rhyolite eruptions found in the North Atlantic and Mediterranean around this time period include the Cape Riva, from the Hellenic Arc, dated to 22,157-21,567 Cal BP (Lee et al., 2012) and the Guneydag and Korudag eruptions of Acigöl volcano in Central Anatolia, dated to 23,800 \pm 900 and 24,900 \pm 900 years BP respectively (Schmidt et al., 2011). Whilst the Acigöl tephra layers show some compositional overlap on both major and minor elements (Fig. 5b), the distances required for ash to be transported against the prevailing circulation, over $3500 \mathrm{~km}$ away, almost certainly precludes a correlation with TAF_S1_R4. No Icelandic or Aeolian rhyolites are currently known from this time period. In the case of Iceland, this may be a preservation bias due to LGM ice cover and associated erosion of comparable tephra records. 
Accepted for publication in Quaternary Science Reviews on 05/09/2014

iii. TAF_S2_R16

Tephra glass shards in layer 16 were small $(<60 \mu \mathrm{m}$ longest axis length) and vesicular (with both open and tightly closed vesicles), which made isolation and analysis of tephra shards very difficult and no compositional data were achieved for this layer.

\subsubsection{Sector 8}

Cryptotephra was recovered in low concentrations in the top $18 \mathrm{~cm}$ of the Yellow Series, in layer Y1, Sector 8 (Fig. 4). Glass shards display elongated vesicles and fluted structures and are the largest observed in the site, with longest axis lengths of up to $100 \mu \mathrm{m}$. To establish if the $18 \mathrm{~cm}$ spread of tephra was all from the same eruption, two samples were picked and analysed: one sample from 4-8 cm and one from 10-12 cm. The samples returned matching rhyolite compositions (Tables 1 and 2; Fig. 5e). The sediments of Y1 are characterised by finely laminated, fine to medium sands, indicating emplacement by gentle wash processes. The distribution of the tephra and the homogeneous composition is therefore likely reflecting the time taken to wash in all of the tephra shards from the catchment, following a single volcanic event.

The major and minor element composition of this rhyolite tephra is similar to that observed in TAF_S1_R4. However, dating of the sediments at the top of Y1 to 15.6-14.8 ka Cal BP (Barton et al., 2013) indicates that TAF_S8_Y1 is around 10,000 years younger than TAF_S1_R4. Distinctly different archaeological industries in the layers concerned also supports the dating evidence. Multiple rhyolitic tephra from Icelandic and Aeolian volcanoes have been described from distal localities in this timeframe (Davies et al., 2012; Albert et al., 2012). The composition of these tephra layers are plotted in Fig. 5 for comparison. On major elements similarities are seen between TAF_S8_Y1 and the Icelandic Penifiler and Borrobl tephra layers (14,140-13,680 years BP and 14,050-13,680 years BP respectively, Matthews et al., 2011) as well as the Lipari Gabelotto Fiumibainco from Lipari, Aeolian Islands. However, comparison of the limited available trace elements shows that tephra from both of these sources is distinctly different from TAF_S8_Y1. The source of the cryptotephra in TAF_S8_Y1 therefore remains unknown.

\subsection{Rhafas}

Small quantities of tephra $(<7$ shards counted per $4 \mathrm{~cm}$ unit) were located toward the top of a column taken through Section 1 square G6, inside the cave (Mercier et al., 2007). This is likely to be a condensed equivalent of Wengler's bed 4 complex, pre-dating 80-90 ka BP Mousterian artefacts (Mercier et al., 2007). No compositional data has been produced from this tephra layer, precluding identification of the volcanic source. 
This site is not particularly well placed to trap cryptotephra, lying near the crest of the local topography, with only a small overland catchment area. Furthermore it appears likely that the original cave passage was longer, the outer section having been progressively eroded and unroofed. However, should any tephra find its way into the site, one would expect it to be well-preserved and to show reasonable stratigraphic resolution. The carbonate-rich sediments within the cave contain low concentrations of limestone clasts, set in poorly expressed but broadly horizontal lenticular bedding, suggesting wash as an input mode for the fines. The interior cave zone that was sampled shows only low levels of bioturbation and no strong diagenetic effects (Mercier et al., 2007). The deeper parts of the sequence (not sampled here) have fewer limestone clasts and laminar bedding, probably representing better contexts for cryptotephra preservation. Thus, despite the low concentrations of tephra shards present in the sampled section, further systematic cryptotephra investigation at this site could be worthwhile.

\subsection{Haua Fteah}

Cryptotephra investigations at the Haua Fteah were carried out in collaboration between RESET and the Cyrenaican Prehistory Project (Barker et al., 2010) and results contribute to the new Bayesian-based chronology for the site and are discussed in full in Douka et al. (2014a). The site is ideal for both the capture and preservation of cryptotephra. It is a partially-roofed, partially in-filled broadly oval-shaped karstic doline, with a high, broad north-facing cave mouth with little or no intervening landmass occurring between the site and tephra sources in Italy, Greece and Anatolia. Sediment of aeolian origin is important in the cave fill, although much has been emplaced by colluvial in-wash from the immediate catchment and local rockfall processes within the cave. Throughout the sequence, the sediments display very clean upper and lower boundary interfaces indicating an episodic depositional regime which is minimally affected by macro-scale postdepositional mixing and bioturbation (Hunt et al., 2010; Inglis, 2012; Douka et al., 2014a). Work at the site has revealed one visible tephra (context 426) and three cryptotephra layers (contexts 441/442, 513,526/527), in samples from the west-facing section of the Middle Trench (Fig. 6). Of these, the youngest three have been successfully identified and correlated to dated eruptions of Italian volcanoes (Douka et al., 2014a).

\section{i. HF_T426}

Context 426 is a $\sim 1 \mathrm{~cm}$ thick visible tephra layer that can be traced laterally across the Middle Trench (Fig. 6) (also see Fig. S4 in Douka et al., 2014a). The tephra has been chemically correlated to the eruption of the Biancavilla Ignimbrite tephra from Mount Etna, $\sim 850 \mathrm{~km}$ away (Coltelli et al., 
Accepted for publication in Quaternary Science Reviews on 05/09/2014

2000; Albert et al., 2013). Tephra from this eruption, dated to 17.61-17.07 ka Cal BP (Kieffer, 1979, calibrated with IntCal13: Reimer et al., 2013, Bronk Ramsey et al., this issue), has been found in many archives across the central Mediterranean. High concentrations of this tephra were reworked throughout the upper part of the sampled section (Fig. 6), preventing further detection of cryptotephra layers in the contexts above HF_T426.

\section{iii. HF_T441/442}

A phono-trachytic cryptotephra ( $1400 \mathrm{~s} / \mathrm{g})$ located at the boundary between contexts 441 and 442 (Fig. 6) has been correlated to the plinian fallout phase of the Campanian Ignimbrite eruption (Fig. 6; Lowe et al., 2012; Douka et al., 2014), from the Campi Flegrei, $1150 \mathrm{~km}$ away. The Campanian Ignimbrite tephra has been ${ }^{40} \mathrm{Ar} /{ }^{39} \mathrm{Ar}$ dated to $39.28 \pm 0.11 \mathrm{ka} \mathrm{BP}(95.4 \%$ confidence interval, De Vivo et al., 2001), providing the most precise age estimate in the Haua Fteah age model (Douka et al., 2014a).

\section{iii. HF_T513}

A second phono-trachytic cryptotephra layer from the Campi Flegrei was found in very low concentration ( $<86 \mathrm{~s} / \mathrm{g}$ ) in context 513 (Fig. 6). This layer has been correlated to tephra layer TM20-2a, described from the varved sediments sequence of Lago Grande di Monticchio, southern Italy (Wulf et al., 2007). TM-20-2a is dated to of $68.62 \pm 2 \mathrm{ka} \mathrm{BP}$ (ca. 3\% varve counting error).

\section{iv. HF_T526/527}

The lowermost cryptotephra found in the Haua Fteah could not be identified. Variable shard morphologies and mixed chemical rhyolitic and trachytic compositions indicated that the horizon is most likely the results of input of tephra from multiple eruption events over an unknown duration. Contexts 526 and 527 lie within sedimentary facies 5, which has a modelled age of 75.6-65.3 ka BP (Douka et al., 2014a). Few tephra layers are well described for this time frame (Blockley et al., in review), however possible rhyolitic sources are known from the Hellenic Arc and Anatolian Province (Tomlinson et al., this issue).

\subsection{Sodmein Cave}

Sodmein is a large but quite shallow cave standing at the base of a significant limestone cliff, with a 'hogback' above, likely to give moderate overland catchment. Airborne tephra is likely to have entered the cave via its wide opening; however there is also some potential for more delayed input of tephra through known major fissures and avens. The sediments are generally reported to show loose packing, irregular thicknesses, lenticular units and common scree; there are some laminated 
Accepted for publication in Quaternary Science Reviews on 05/09/2014

intervals, interpreted as local aeolian units. Organic units are common, containing herbivore dung, mammal (sometimes carnivore) coprolites and guano. Enhanced limestone corrosion has been noted in some of these organic layers, which may indicate some potential for leaching or dissolution of tephra glass shards (Pollard et al., 2003).

Column samples taken from the sediment sequence revealed the presence of cryptotephra in at least two $\sim 50 \mathrm{~cm}$ deep zones of the stratigraphy (Fig. 7), which may indicate prolonged input of tephra into the cave system. Within these broader zones, distinct peaks in glass shard concentrations were identified at 25-30 cm and 150-155 cm, yielding 288 and 279 shards per gram of dried sediment respectively. The upper cryptotephra $(\mathrm{SC} 1)$ lies at the top of layer $\mathrm{C} 4$, at the top of the Pleistocene sequence and close to the boundary with the Holocene. The lower cryptotephra (SC2) is located at the interface of layer $\mathrm{H}$ and the overlying layer G-base, believed to be of MIS 4 age.

\section{i. $\mathrm{SC} 125-30 \mathrm{~cm}$}

Cryptotephra from this level show three compositional components that are individually classified here (Fig. 8): (1) a dominant component that shows a homogeneous calc-alkaline (CA) rhyolitic affinity $\left(n=16 ; 75.7 \pm 0.6\right.$ wt. $\% \mathrm{SiO}_{2} ; 3.5 \pm 0.2 \mathrm{wt}$. $\left.\% \mathrm{~K}_{2} \mathrm{O}\right)$; (2) a small population shows a high potassium calc-alkaline (HKCA) rhyolitic affinity $\left(n=2 ; 74.5 \mathrm{wt} . \mathrm{SiO}_{2} ; 4.4 \mathrm{wt} . \% \mathrm{~K}_{2} \mathrm{O}\right)$; (3) a second small population shows a K-trachyte affinity $\left(n=2 ; 61.7\right.$ wt.\% $\mathrm{SiO}_{2}$; 8.7-9.0 wt.\% $\mathrm{K}_{2} \mathrm{O}$ ) (Table 4). The dominant CA rhyolitic glass composition (component 1) can be correlated to central Anatolian volcanism and the products of Erciryes Dagi (Fig. 8b-c), c.1300 km north of Sodmein Cave. Geochemical data show very good agreement with the glass compositions of the early Holocene eruptions of this volcano. Three early Holocene eruptive units are recognised on the slopes of Erciyes Dagi: Dikkartın, Karagüllü, and Perikartın. These eruptions are estimated to span between 10,200 and 7900 Cal BP (Sarikaya et al., 2006; 2009). It is difficult to compositionally distinguish between these proximal tephra deposits, however, it does appear that component 1 of cryptotephra $\mathrm{SC} 125-30 \mathrm{~cm}$ is very homogeneous, a consistent feature seen in the youngest eruptive unit, Dikkartin (Fig. 8). Hamann et al. (2010) report the S-1 tephra from the eastern Levantine Sea, dated to $9130-8700 \mathrm{Cal} \mathrm{BP}$, and correlate this tephra to the Dikkartin eruption. There is a very strong agreement between the S-1 tephra and SC1 25-30 cm identified at Sodmein Cave (Fig. 8d) and the correlation of these two distal tephra layers supports a southerly dispersal for the Dikkartin eruption of Eciryes Dagi.

The HKCA rhyolitic glasses $(n=2)$ of component 2 are similar in composition to the rhyolitic products of Nemrut Dagi (Eastern Anatolia) (Fig. 8a-d), whilst the K-trachytic glasses $(n=2)$ of 
Accepted for publication in Quaternary Science Reviews on 05/09/2014

component 3 correspond to glasses erupted from Campi Flegrei, southern Italy (Fig. 8a). Given the strength of the geochemical correlation between the dominant glass component (component 1) of cryptotephra SC1 $25-30 \mathrm{~cm}$, the early Holocene explosive activity at Erciyes Dagi and the S-1 tephra in the Levantine Sea, we adopt the age of the latter and suggests a date of 8700-9130 Cal BP can be imported to the depth of $25-30 \mathrm{~cm}$ in Sodmein Cave.

\section{ii. SC2 $150-155 \mathrm{~cm}$}

This cryptotephra has a dominant Na-rich trachyte component $\left(66.3 \pm 1.7\right.$ wt.\% $\mathrm{SiO}_{2} ; 7.2 \pm 2$ wt.\% $\mathrm{Na}_{2} \mathrm{O}$ and $5.4 \pm 0.3$ wt. $\% \mathrm{~K}_{2} \mathrm{O}$ ), whilst a single outlying analysis shows a rhyolitic with 73.9 wt.\% $\mathrm{SiO}_{2}$ and again showing elevated $\mathrm{Na}_{2} \mathrm{O}$ concentrations affinity (Table 4, Fig. 8). Comparisons with circum-Mediterranean explosive volcanism fail to offer a potential source for this tephra. Thus the provenance of this tephra remains unknown. Volcanic sources from further south and east of Sodmein cannot be ruled out (e.g. Arabian Peninsula, Ethiopian Rift), but without comparative data it is difficult to explore this option at present.

\section{Discussion}

The discovery of cryptotephra in stratigraphic contexts at sites across a broad area of North Africa demonstrates the proof of concept that this technique offers high potential for dating and correlating archaeological and environmental records during the Pleistocene. Individually, the sites of Taforalt (Morocco), Haua Fteah (Cyrenaica, Libya) and Sodmein (Egypt) have long sequences of MSA/MP and LSA layers which contain identifiable cryptotephra horizons that can be either directly correlated with known volcanic events or that can be placed within detailed chronological sequences and provide a means of ordering these distal tephras both stratigraphically and temporally. Whist it is not possible to draw too many conclusions based on the absence of tephra within the other investigated sites, our finding suggest that a large catchment, availability of sediment entry points and undisturbed sediment accumulation are key to preserving tephra within this type of archives.

\subsection{Refining chronologies of human evolution}

At the Haua Fteah, three well-dated cryptotephra layers have significantly improved our understanding of the timing of cultural transitions as well as providing tie-points for making correlations across very wide geographical areas and with other archaeological sites.

The oldest characterised tephra at the Haua Fteah (HF_T513) occurs well within the LevalloisoMousterian sequence (there is $\sim 1 \mathrm{~m}$ of sediment with similar finds described by McBurney beneath this tephra) and provides a varve age of $68.62 \pm 2 \mathrm{ka} \mathrm{BP}$. This date agrees well with other evidence 
Accepted for publication in Quaternary Science Reviews on 05/09/2014

that suggests a general age of around 70.8-66.7 ka BP for these layers and for the dating of two $H$. sapiens mandibles (Douka et al., 2014a). The dating of the mandibles places them within the timeframe of the dispersal of modern humans out of Africa and brings more sharply into focus the question of whether these were late surviving archaic $H$. sapiens or part of the exodus of the first modern humans to leave Africa at 65-60 ka BP (Mellars, 2006). Clearly a re-study of the mandibles to clarify their taxonomic status would now be of great benefit.

The discovery of the Campanian Ignimbrite in the Haua Fteah, located in the deeper Dabban layers above a sterile gap with the underlying Levalloiso-Mousterian sequence, provides a minimal date of $\sim 39.3 \pm 0.1 \mathrm{ka}$ (De Vivo et al., 2001) for the early Dabban. On stratigraphic grounds it is possible to infer that the actual age of oldest Dabban lies closer to $46-41 \mathrm{ka}$ BP, before the CI eruption (Douka et al., 2014a). If the Dabban marks a genuine break with the underlying LevalloisoMousterian layers (as the gap in cultural layers suggests), it may have an important bearing on the spread of people and ideas into this region possibly paralleling the entry of early modern humans into southern Europe at 45-43 ka BP (Benazzi et al., 2011). Although the Dabban cannot be directly compared to some of the earliest European Upper Palaeolithic technologies (e.g. Uluzzian, Douka et al., 2014b) it does nonetheless suggest that the pattern of rapid migration of modern humans - whether out of Africa or re-entering North Africa via the Levant - is highly complicated but can now begin to be realistically investigated based on the availability of this new dating evidence.

Finally, the Biancavilla Ignimbrite is likewise important because it provides a precise age estimate (17.9-16.8 ka BP; Kieffer, 1979) associated with an early phase of the LSA

Oranian/Iberomaurusian at Haua Fteah. Together with new AMS radiocarbon determinations, this provides the first reliable confirmation that the Iberomaurusian in this region is probably younger compared with that of the neighbouring Maghreb (Barton et al., 2013). This may have implications for understanding a later dispersal of human populations known as Mechta-Afalou types and supports the hypothesis of an indigenous development of the Iberomaurusian in the Maghreb (Barton et al., 2013).

\subsection{Correlating between archives}

At present, no tephra layers have been found that directly link between our investigated North African archives. Taforalt, Sodmein Cave and Haua Fteah each record tephra from different volcanic regions, demonstrating the importance of a detailed and far-reaching tephrostratigraphic record, including proximal datasets, if we wish to make full use of tephra layers as event- 
Accepted for publication in Quaternary Science Reviews on 05/09/2014

stratigraphic horizons. However, whilst there is a wealth of compositional data on many European volcanic centres, such as those found in Iceland, Italy and the Eastern Mediterranean, not all volcanic sources and events are as well constrained as these. For example, very little glass shard data are available from Quaternary eruptions of the volcanoes in the Canaries and Azores archipelagos. Both centres are reported to have had multiple caldera-forming eruptions during the Late Quaternary (Ablay and Martí, 2000; Queiroz et al., 2008; Gertisser et al., 2010) and lie within a few thousand kilometres of Morocco and within a westerly atmospheric circulation pattern that would suggest these as a likely source for tephra in sites across NW Africa. The discovery of four cryptotephra horizons at Taforalt, from likely Atlantic and Mediterranean volcanoes, as well as hints of tephra within the stratigraphy of Dar es-Soltane 1 and Rhafas, indicate future potential for linking MSA and LSA archaeological sites across and beyond the Maghreb.

At Taforalt perhaps the most promising tephra for future work is TAF_S8_Y1. The horizon lies very close to the sediment boundary between the Yellow and Grey Series deposits, for which there is a modelled ${ }^{14} \mathrm{C}$ age of $15,110-14,940 \mathrm{Cal} \mathrm{BP}$ (at $68.2 \%$ probability) (Barton et al., 2013). The cryptotephra is associated with a phase of increasing climatic humidity in the cave and a recognisable change in the composition of the LSA/Iberomaurusian assemblages (Barton et al., 2013). If this can be replicated at other sites in Morocco and the Maghreb it would make a significant contribution to our understanding of local and regional patterning in this cultural substage.

Lower in the stratigraphy at Taforalt,TAF_S1_R2 is also of some interest because it lies just above layers dated to $\sim 25 \mathrm{ka}$ BP that contain an assemblage dominated by quartzite flakes that is different from the bladelet-based Iberomaurusian and which we tentatively identify with a very late MSA (Barton et al., 2013). The fact that this industry is partly sandwiched between two cryptotephras (TAF_S1_R4 is just below), may turn out in future to be useful for dating the MSA-LSA transition and making precise comparisons between regional archives.

Interestingly, the best example of using tephra as a time-synchronous correlation tool between archaeological archives is given by the occurrence of the Campanian Ignimbrite in the Haua Fteah. Whilst not yet located in any other North African site, the Campanian Ignimbrite has been located in a number of Middle to Upper Palaeolithic records from southern Europe and even into southern Russia (Lowe et al., 2012), where it provides a precise datum around which the record of $H$. sapiens in North Africa can be directly compared to that in another continent.

\section{Conclusions}


Accepted for publication in Quaternary Science Reviews on 05/09/2014

In this paper we have presented the results of the first systematic investigation of cryptotephras from sites across North Africa. Tephras and cryptotephras of different geochemical compositions have been detected at three cave sites (Taforalt, Haua Fteah and Sodmein). In the case of Haua Fteah considerable success has been achieved in singling out proximal volcanic sources which are well dated and provide a chronological framework for understanding the ages of the sediments in which the tephra shards occur. These have added significantly to our knowledge of cultural transitions within the MSA and for the LSA chronology of this cave and provide age estimates for two $H$. sapiens mandibles in the MSA (Levalloiso-Mousterian) layers. Although the proximal volcanic sources for cryptotephra layers in Taforalt and Sodmein Caves are at present imprecisely known they provide strong circumstantial evidence for long distance transport of tephra shards from volcanoes on the Azores and from Anatolian sources, respectively. In each of these instances the tephra signal is sufficiently strong to show the potential for extending the technique to other terrestrial sites from across North Africa to the Levant, as well as adjacent offshore marine deposits.

\section{Footnote 1}

Except where stated all radiocarbon dates are calibrated and expressed in calendar years before present (Cal BP).

\section{Footnote 2}

UK Natural Environment Research Council project "Response of humans to abrupt environmental transitions", 2008-2013. www.c14.arch.ox.ac.uk/reset/

\section{Acknowledgements}

RNEB would like to thank the various institutions in North Africa that participated in the project and provided permission for access to the sites and research. They comprise the Institut National des Sciences de l'Archéologie et du Patrimoine (Morocco), the Institut du Patrimoine (Tunisia), the Department of Antiquities of Libya, the Ministry of State for Antiquities in Egypt and the Egyptian Mineral Resources Authority. The research in Morocco was supported by grants from the Natural Environment Research Council (NER/T/S/2002/00700 and NE/E015670/1 and the NERC radiocarbon facility), Protars P32/09-CNRST (Morocco), the British Academy, Oxford University and the Leverhulme Trust (F/08 735/F). Also warmly thanked are J-J. Hublin and S. McPherron of the Max Planck Institute at Leipzig for supporting the work at Rhafas Cave. CSL has been funded by a Leverhulme Trust Early Career Fellowship and would like to thank Emma Tomlinson (Trinity College Dublin) for LA-ICP-MS results, José Pachero and Stefan Wastegard for valuable discussions about tephra provenance, and Simon S.P.E. Blockley, Victoria L. Cullen and Eileen 
Accepted for publication in Quaternary Science Reviews on 05/09/2014

Jacob for their assistance with samples both in the field and the laboratory. LF acknowledges

financial support of the European Research Council (Advanced Investigator Grant230421: TRANS-

NAP project: Cultural Transformations and Environmental Transitions in North African

Prehistory), the Society for Libyan Studies, the Leakey Foundation, and the NERC Radiocarbon

Facility. The work in Egypt was funded by Deutsche Forschungsgemeinschaft (DFG). 
Accepted for publication in Quaternary Science Reviews on 05/09/2014

\section{Tables}

\section{Table 1.}

Summary of the eight sites investigated for cryptotephra across North Africa to the Levant as part of the RESET project. References are given to key papers on each site where further detail on the archaeological sequences can be found.

\section{Table 2.}

Major and minor element single-grain glass shard compositions (WDS-EMPA) for cryptotephra horizons in Taforalt, and associated secondary glass standard analyses. Data presented as normalised (water free) values, with original analytical totals.

\section{Table 3.}

Trace element single-grain glass shard compositions (in ppm) for cryptotephra horizons

TAF_S1_R2 and TAF_S8_Y1, as well as associated secondary glass standard analyses.

TAF_S1_R2 was analysed both by LA-ICP-MS and SIMS, the data is comparable within 2 sigma uncertainties. TAF_S8_Y1 was analysed only using SIMS.

\section{Table 4.}

Major and minor element single-grain glass shard compositional data (WDS-EMPA) for the Sodmein Cave cryptotephra layers SC1 and SC2 and associated secondary glass standard analyses. Data presented as normalised (water free) values, with original analytical totals.

\section{Figure captions}

\section{Fig. 1.}

Distribution of study sites in North Africa and the Levant and volcanic centres discussed in the text. 
Accepted for publication in Quaternary Science Reviews on 05/09/2014

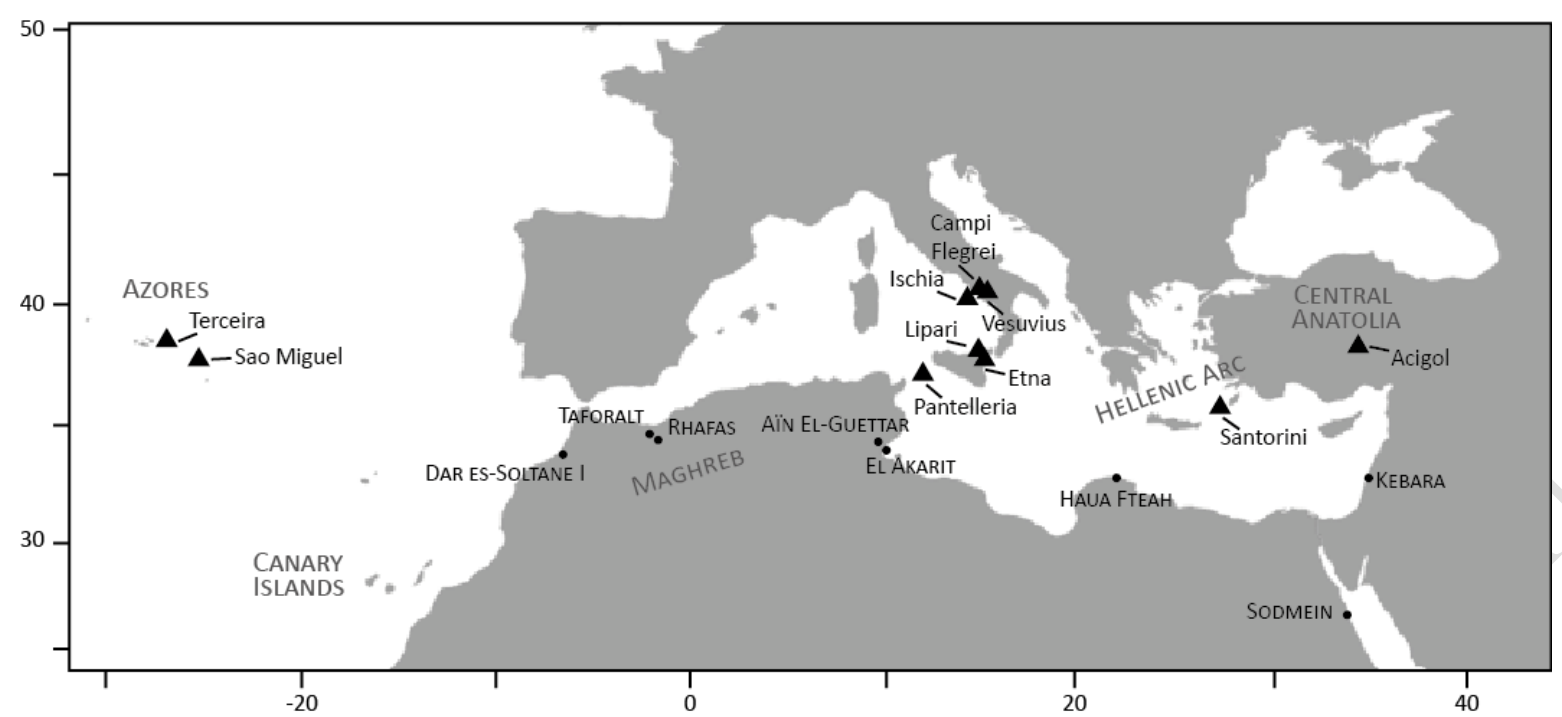

Fig. 2.

Plan of excavations in Taforalt, showing the position of the different sectors (1-2 and 8) sampled for cryptotephra. 


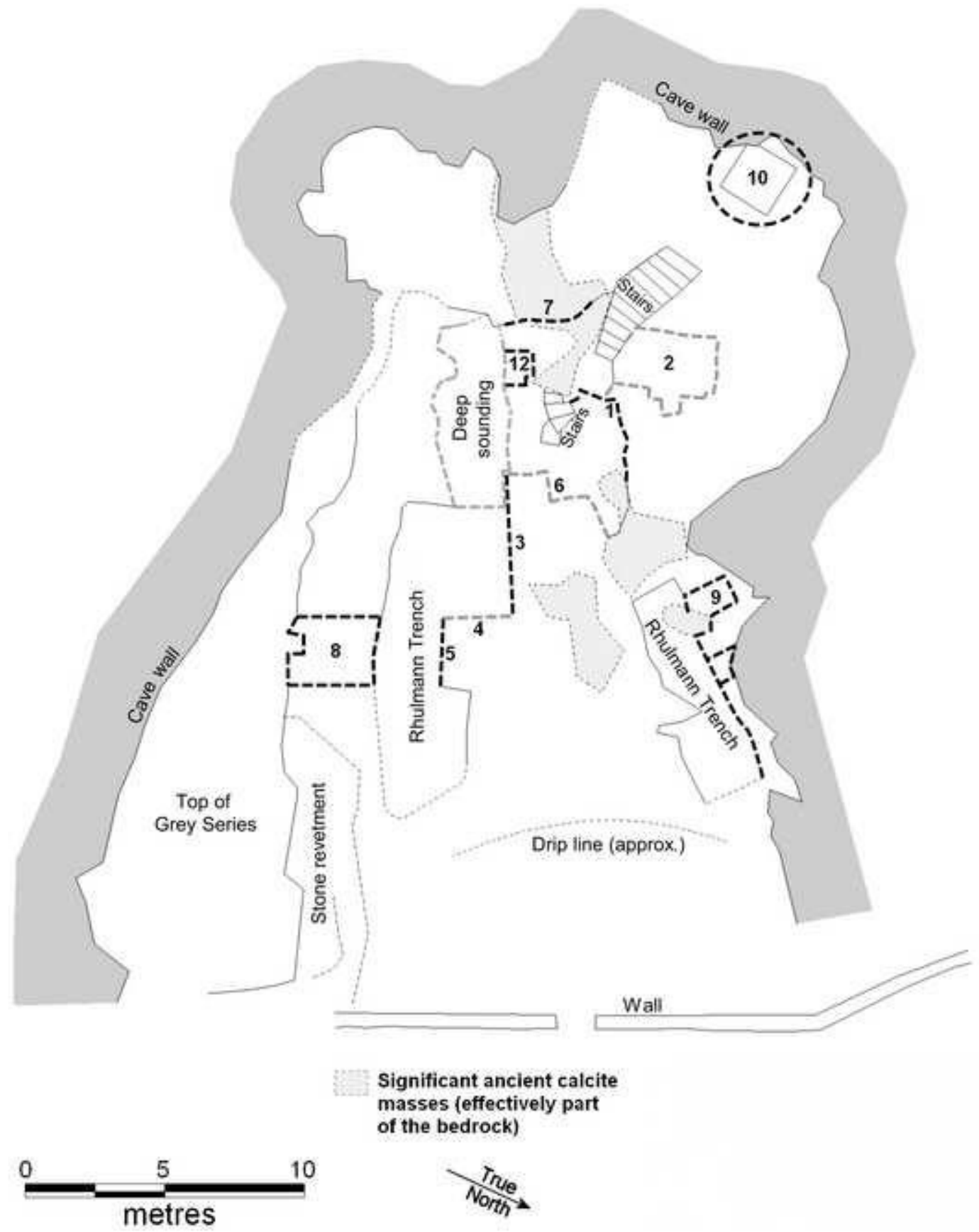

Fig. 3.

Taforalt: Sector 2 section showing position of overlapping sample columns (A-D) and relationship to sampled units (R layers) and their dating (Bouzouggar et al., 2008; Barton et al., 2013). A: R1-4; B and C: R16; D: R5-13. The tephra glass shard concentrations in R1-4 (column A) are shown. 
Accepted for publication in Quaternary Science Reviews on 05/09/2014

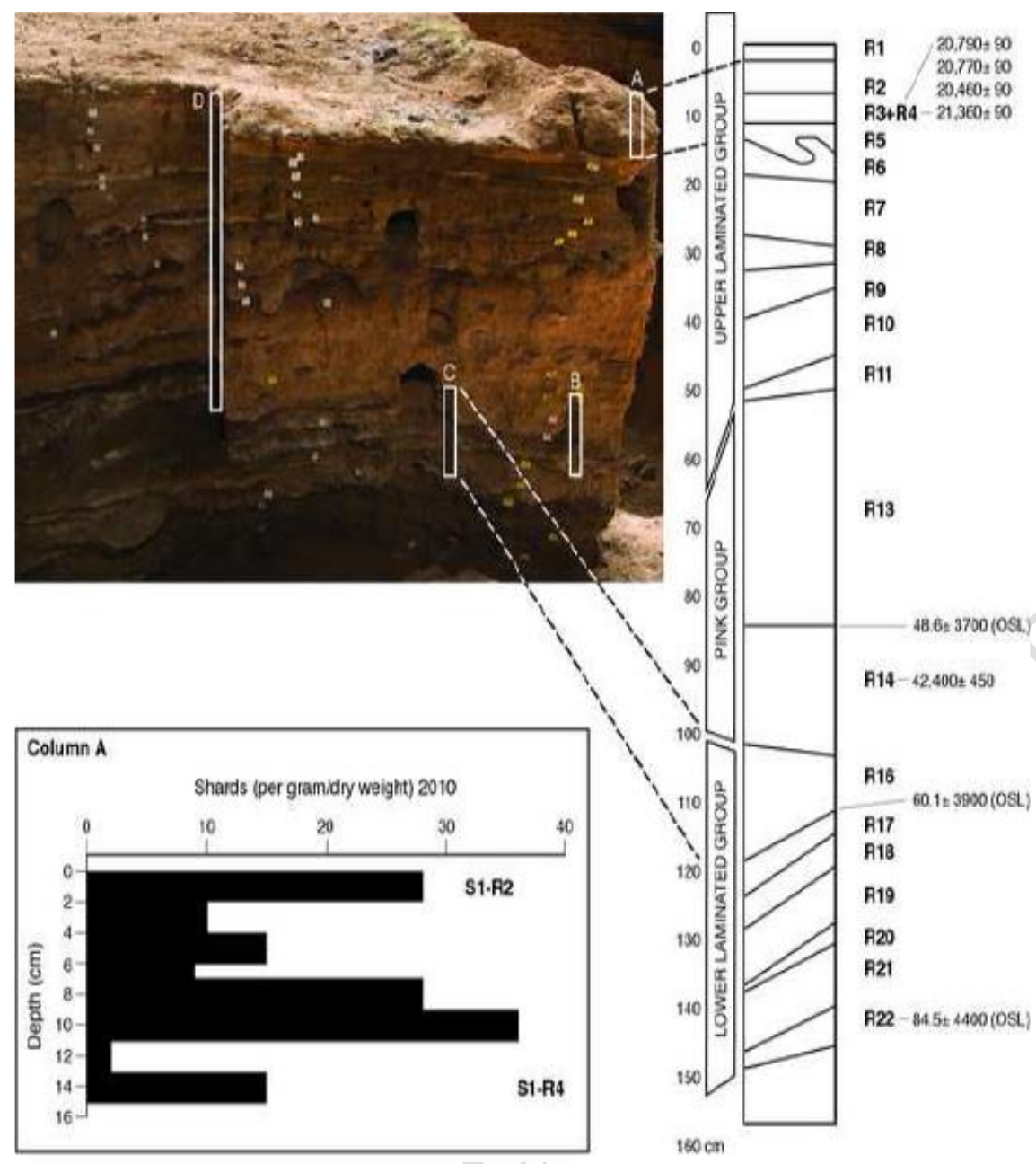

Fig. 4.

Taforalt: Sector 8 section showing position of sample column alongside a vertical schematic section through the sediments with radiocarbon timescale (Bouzouggar et al., 2008; Barton et al., 2013). The tephra glass shard concentrations around S8_Y1 are shown. 


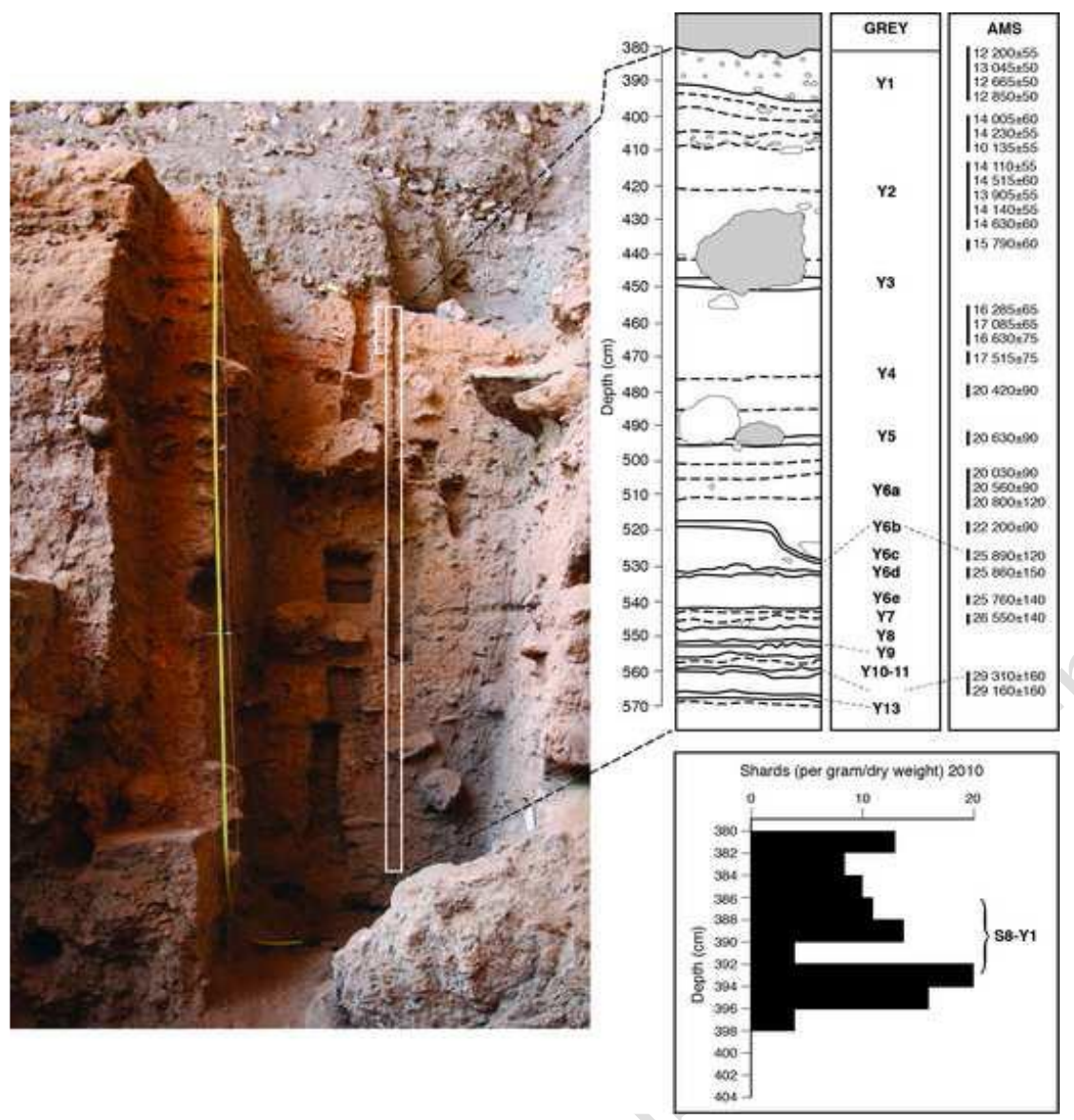

\section{Fig. 5.}

Glass composition of the Taforalt tephra layers (WDS-EMPA, LA-ICP-MS and SIMS) and comparative reference data. (a) total-alkali-silica diagram showing compositional classification of all analysed tephra layers from Taforalt. Compositional envelopes for a range of trachytic and rhyolitic tephra layers from North Atlantic and Southern European volcanic centres plotted to show possible correlations (data from Wulf et al., 2004; Beier et al., 2006; Gertisser et al., 2010; Matthews et al., 2011; Lane et al., 2012a,b; Albert et al., 2013; Tomlinson et al., this issue). (b) Biplot of $\mathrm{Al}_{2} \mathrm{O}_{3} \mathrm{vs} \mathrm{FeO}$ for rhyolitic tephra layers in Sector $1 \mathrm{R} 4$ and Sector 8, showing discrimination from tephra of the Cape Riva, Askja-S, Vedde Ash and Acigol eruptions. (c) Bi-plot of $\mathrm{Al}_{2} \mathrm{O}_{3}$ vs $\mathrm{FeO}$ for trachytic tephra layers in S1_R2, showing discrimination from tephra generated by Terceira volcano and Vesuvius. (d) Bi-plot of Th vs Nb rhyolitic tephra horizons in Sector $1 \mathrm{R} 4$ and Sector 8, showing discrimination from the Lipari Gabelotto Fiumibianco tephra layer. (e) Bi-plot of Th vs $\mathrm{Nb}$ for trachytic tephra horizons in S1_R2, showing discrimination from the TM-14-1 tephra layer. Errors given represent two standard deviations of repeat analysis of the secondary standard StHs6/80-G (Jochum et al., 2005; 2006). 

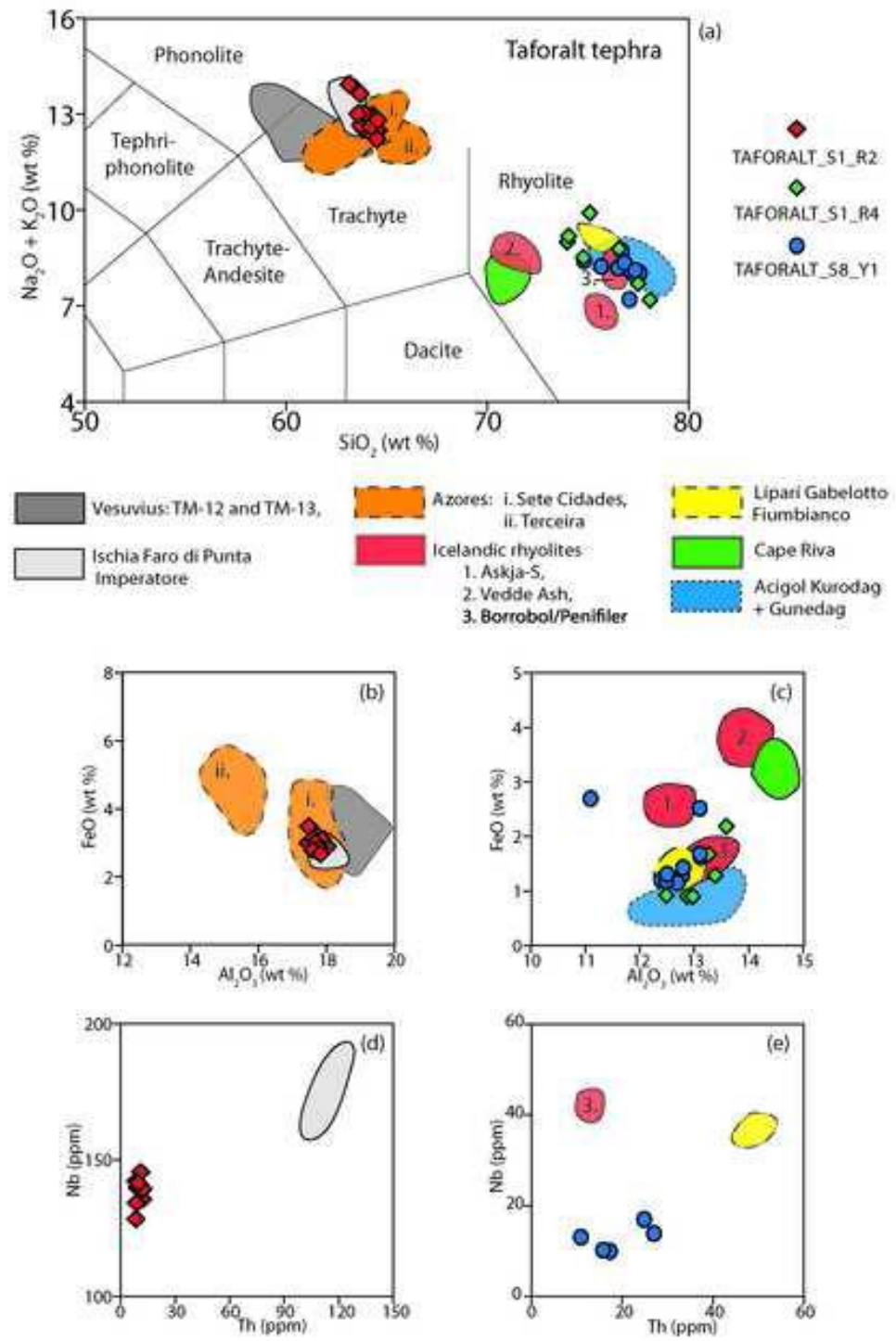

\section{Fig. 6.}

Summary of results from cryptotephra investigations at Haua Fteah, Libya. Tephra glass shard concentrations $(\mathrm{s} / \mathrm{g})$ and correlations alongside the stratigraphy of sample column A (west-facing section, Middle Trench), after Douka et al., 2014a. 
Accepted for publication in Quaternary Science Reviews on 05/09/2014

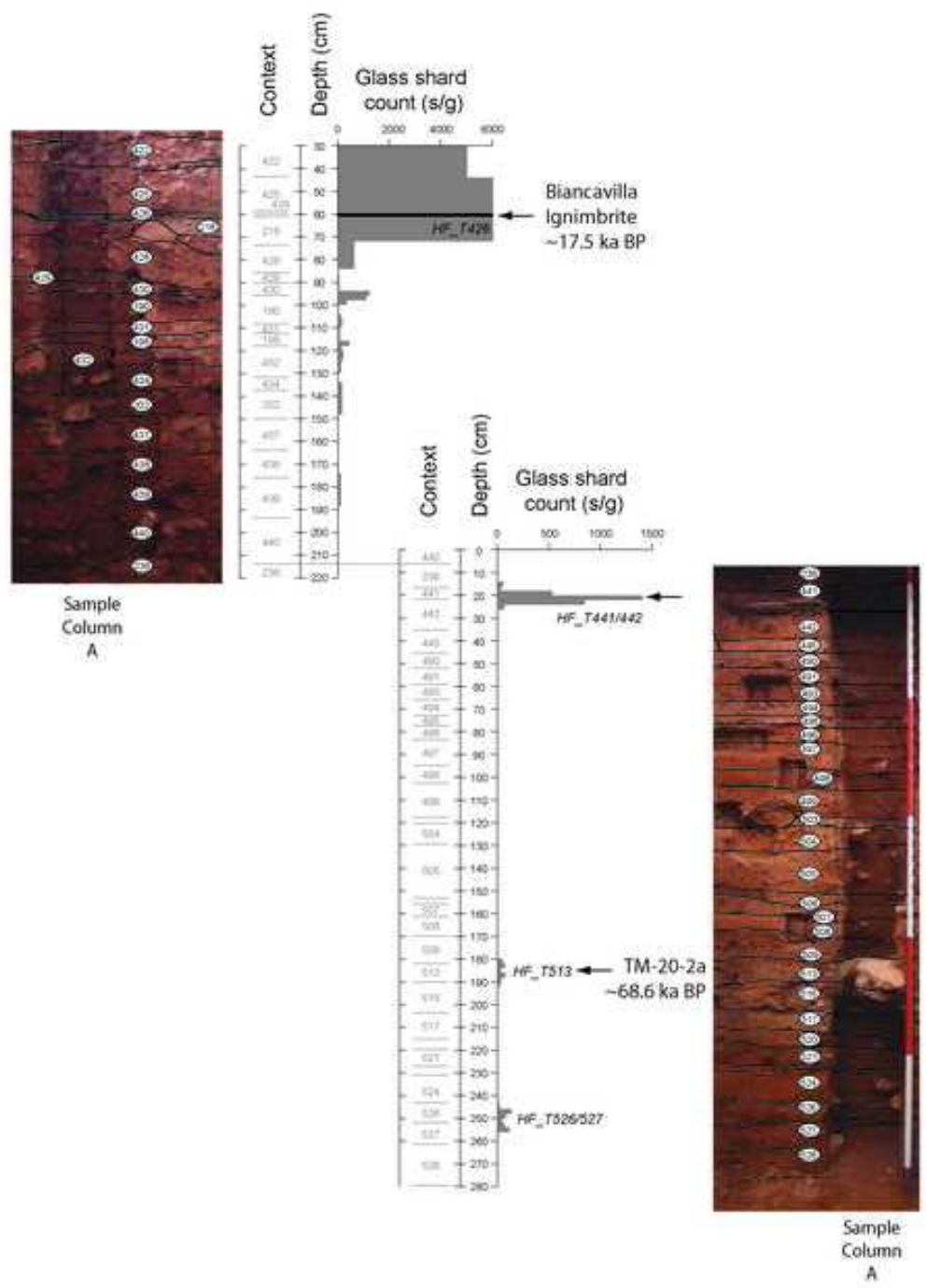

Fig. 7.

A. Plan of the Sodmein Cave and excavations showing the position of Section 1 column sample. B. Stratigraphic context of the sample column, showing position of tephra layers SC1 (tephra 1) and SC2 (tephra 2). C. Tephra glass shard concentrations for the full sample column and around SC1 and SC2 tephra layers. 


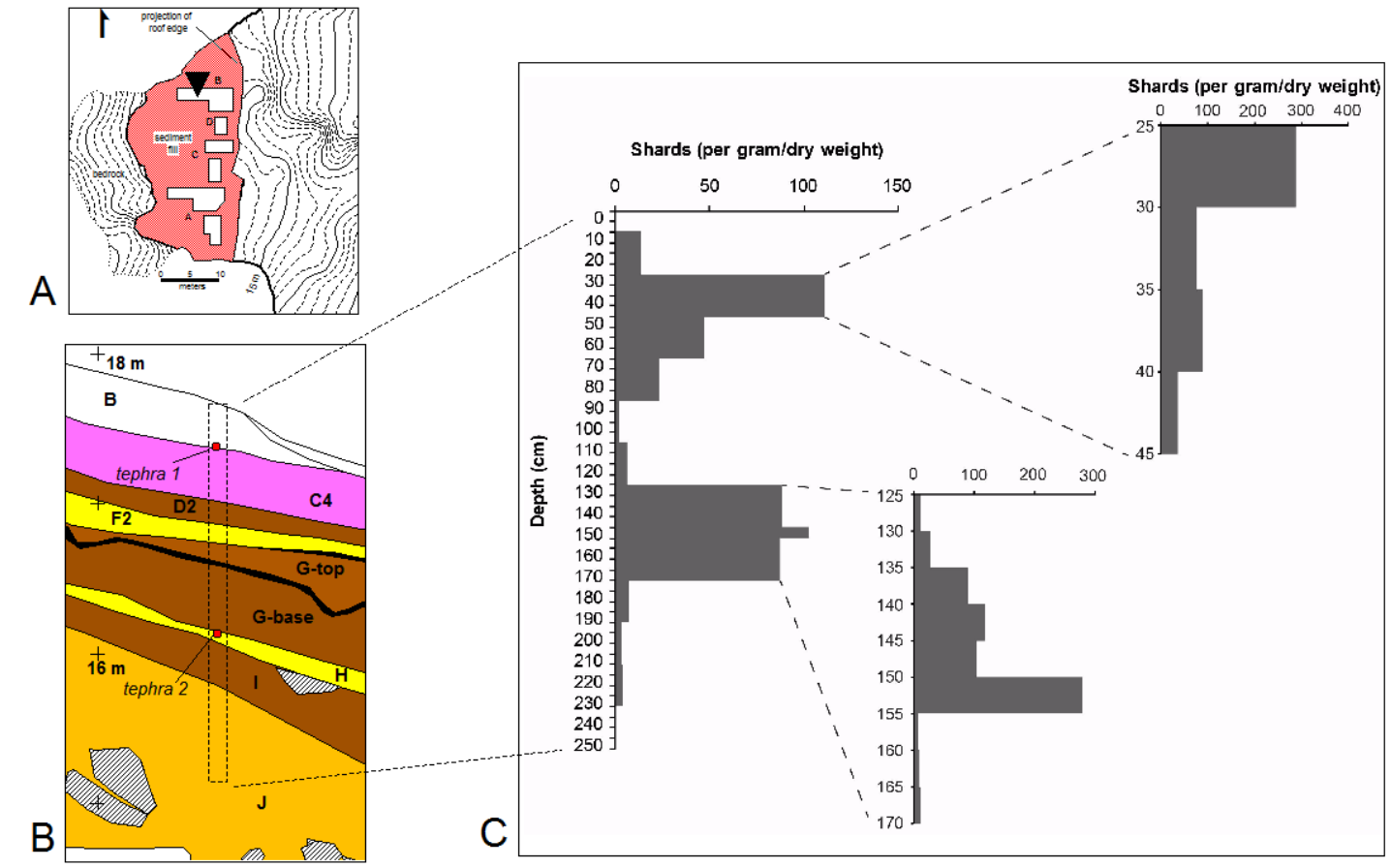

Fig. 8.

Glass compositions of the Sodmein Cave tephra layers (WDS-EMPA) and comparative reference data: (a) total-alkali-silica diagram showing the compositions of the Sodmein tephra layers; also shown are the compositional fields of Mediterranean volcanic centres (Tomlinson et al., this issue;); (b-c) SC1 25-30 cm compared to the compositional fields of Erciyes Dagi (C. Anatolia), Acigol (C. Anatolia), Nemrut Dagi (E. Anatolia) and Salina (Aeolian Islands, Italy) (Albert et al., 2013; Tomlison et al., this issue); (d) SC1 25-30 cm compared to the compositions of the early Holocene eruptions of Erciyes Dagi; Dikkarin, Karagüllü, Perikartini, also given is the composition of the S1 tephra from the Levantine Sea (Hamann et al., 2010). Errors given represent two standard deviations of repeat analysis of the secondary standard StHs6/80-G (Jochum et al., 2005; 2006). 
Accepted for publication in Quaternary Science Reviews on 05/09/2014

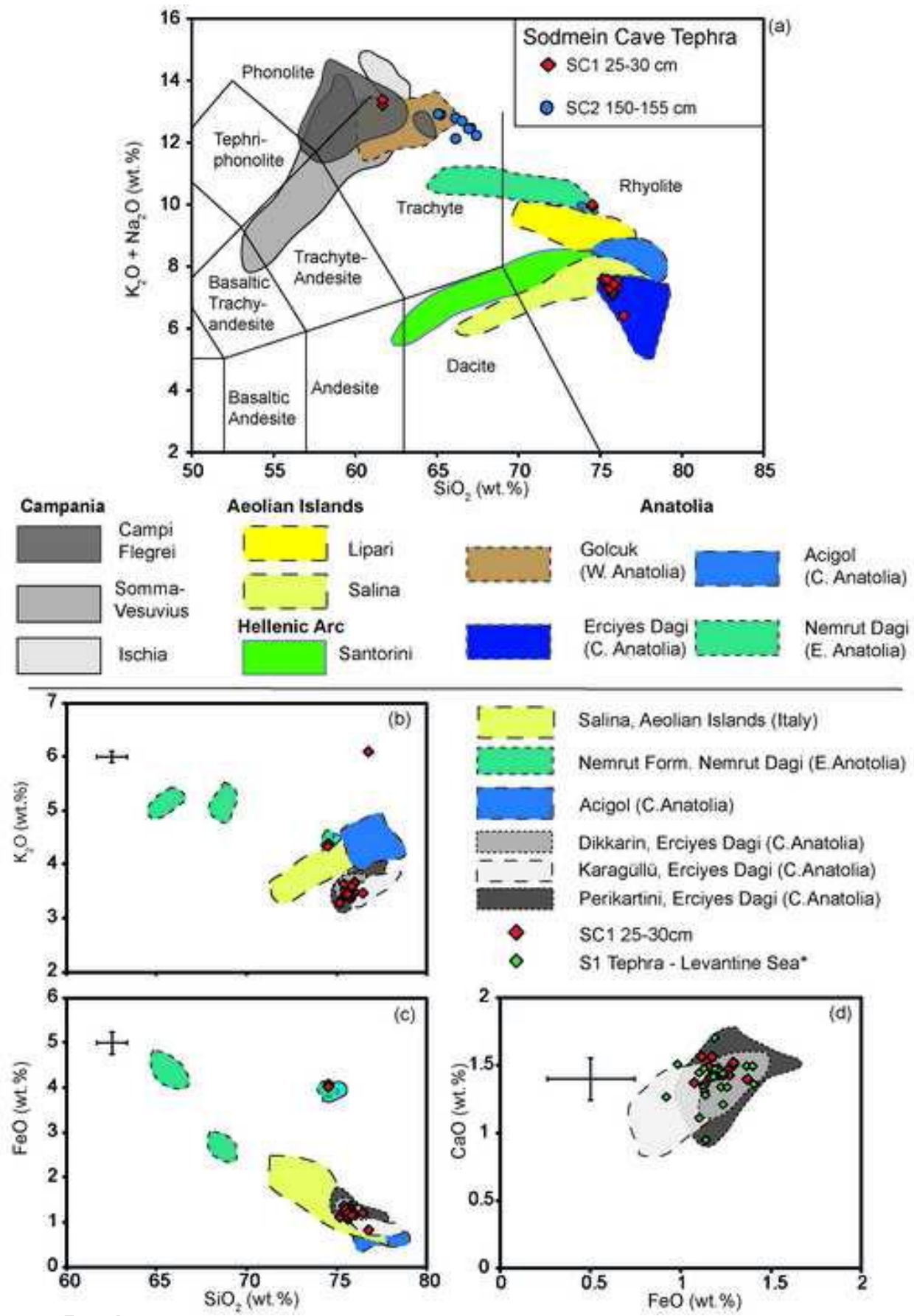




\section{References}

Ablay, G.J., Martí, J., 2000. Stratigraphy, structure, and volcanic evolution of the Pico Teide - Pico Viejo formation, Tenerife, Canary Islands. Journal of Volcanology and Geothermal Research 103, 175-208.

Albert, P.G., Tomlinson, E.L., Smith, V.C., Di Roberto, A., Todman, A., Rosi, M., Marani, M., Muller, W., Menzies, M.A. 2012. Marine-continental tephra correlations: Volcanic glass geochemistry from the Marsili Basin and the Aeolian Islands, Southern Tyrrhenian Sea, Italy. Journal of Volcanology and Geothermal Research 229-230, 74-94.

Albert, P.G., Tomlinson, E.L., Lane, C.S., Wulf, S., Smith, V., Coltelli, M., Keller, J., Lo Castro, D., Manning, C.J., Müller, W., Menzies, M.A. 2013. Late glacial explosive activity on Mount Etna: implications for proximal-distal tephra correlations and the synchronisation of Mediterranean archives. Journal of Volcanology and Geothermal Research 256, 9-26.

Aouadi-Abdeljaouad, N., Belhouchet, L., 2008. Recent prehistoric field research in Central Tunisia: Prehistoric occupations in the Meknassy Basin. African Archaeological Review 25, 75-85.

Aouadi-Abdeljaouad, N., Belhouchet, L., 2012. Middle Stone Age in Tunisia: present status of knowledge and recent advances. In: Hublin, J.-J., McPherron, S. (Eds.), Modern origins: A North African perspective. Springer, Dordrecht, pp. 143-156.

Barham, L.S., Mitchell, P.J., 2008. The first Africans: African archaeology from the earliest toolmakers to most recent foragers. Cambridge University Press, Cambridge.

Barker, G., Hunt, C., Reynolds, T., 2007. The Haua Fteah, Cyrenaica (northeast Libya): renewed investigations of the cave and its landscape, 2007. Libyan Studies 38, 93-114.

Barker, G., Antoniadou, A., Armitage, S., Brooks, I., Candy, I., Connell, K., Douka, K., Drake, N., Farr, L., Hill, E., Hunt, C., Inglis, R., Jones, S., Lane, C., Lucarini, G., Meneely, J., Morales, J., Mutri, G., Prendergast, A., Rabett, R., Reade, H., Reynolds, T., Russell, N., Simpson, D., Smith, B., Stimpson, C., Twati, M., White, K. 2010. The Cyrenaican Prehistory Project 2010: the fourth season of investigations of the Haua Fteah cave and its landscape, and further results from the 2007-2000 fieldwork. Libyan Studies 41, 63-88.

Barton, R.N.E., Bouzouggar, A., Collcutt, S.N., Schwenninger, J-L., Clark-Balzan, L., 2009. OSL dating of the Aterian levels at Grotte de Dar es-Soltan I (Rabat, Morocco) and possible implications for the dispersal of modern Homo sapiens. Quaternary Science Reviews 28, 19141931.

Barton, R.N.E., Bouzouggar, A., Hogue, J.T., Lee, S., Collcutt, S.N., Ditchfield, P., 2013. Origins of the Iberomaurusian in NW Africa: New AMS radiocarbon dating of the Middle and Later Stone Age deposits at Taforalt Cave, Morocco. Journal of Humam Evolution 65 (3), 266-281.

Bar-Yosef, O., Vandermeersch, B., Arensburg, B., Belfer-Cohen, A., Goldberg, P., Laville, H., Meignen, L., Rak, Y., Spth, J.D., Tchernov, E., Tillier, A.-M., Weiner, S. 1992. The excavations in Kebara Cave, Mt. Carmel. Current Anthropology 33, 497-550.

Beier, C., Haase, K.M., Hansteen, T.H. 2006. Magma evolution of the Sete Cidades volcano, São Miguel, Azores. Journal of Petrology 47, 1375-1411. 
Benazzi, S., Douka, K., Fornai, C., Bauer, C.C., Kullmer, O., Svoboda, J., Pap, L., Mallegni, F., Bayle, P., Coquerelle, M., Condemni, S., Ronchitelli, A., Harvati, K., Weber, G.W., 2011. Early dispersal of modern humans in Europe and implications for Neanderthal behavior. Nature 479, 525528.

Blockley, S.P.E., Pyne-O'Donnell, S.D.F., Lowe, J.J., Matthews, I.P., Stone, A., Pollard, A.M., Turney, C.S.M., Molyneux, E.G., 2005. A new and less destructive laboratory procedure for the physical separation of distal glass tephra shards from sediments. Quaternary Science Reviews 24, 1952-1960.

Blockley, S., Brauer, A., Davies, S., Hardiman, M., Harding, P., Lane, C.S., MacLeod, A., Matthews, I.P., Pyne-O'Donnell, S., Rasmussen, S.O., Wulf, S., Zanchetta, G. Tephrochronology and the extended intimate (integration of ice-core, marine and terrestrial records) event stratigraphy 8-128 ka b2k. Quaternary Science Reviews, In review.

van den Bogaard, C., Schmincke, H.-U., 2002. Linking the North Atlantic to central Europe: a highresolution Holocene tephrochronological record from northern Germany. Journal of Quaternary Science 17, 3-20.

Boric, D, Dimitrijevic, V, White, D., Lane, C.S., French, C., Cristiani, E. 2012. Early Modern Human settling of the 'Danube corridor': The Middle to Upper Palaeolithic site of Tabula Traiana Cave in the Danube Gorges (Serbia). Antiquity 86, 334, Antiquity Project Gallery.

Bouzouggar, A., Barton, R.N.E., Blockley. S., Bronk-Ramsey, C., Collcutt, S.N., Gale, R., Higham, T.F.G., Humphrey, L.T., Parfitt, S., Turner, E., Ward, S., 2008. Re-evaluating the age of the Iberomaurusian in Morocco. African Archaeological Review 25, 3-19.

Bouzouggar, A., Barton, R.N.E., 2012. The identity and timing of the Aterian in Morocco. In: Hublin, J.-J., McPherron, S. (Eds.), Modern origins: A North African perspective. Springer, Dordrecht, pp. 93-105.

Bronk Ramsey, C., Albert, P., Blockley, S.P.E., Hardiman, M., Housley, R.A., Lane, C.S., Lee, S., Matthews, I.P., Smith, V.C., Lowe, J. Improved age estimates for important Late Quaternary European tephra horizons in the RESET lattice. Quaternary Science Reviews, this issue.

Caton-Thompson, G., 1946. The Aterian industry: its place and significance in the Palaeolithic world. J. R. Anthropol. Inst. G.B. Irel. 76 (2), 87-130.

Coltelli, M., Del Carlo, P., Vezzoli, L., 2000. Stratigraphic constraints for explosive activity in the past $100 \mathrm{ka}$ at Etna Volcano, Italy. International Journal of Earth Sciences 89 (3), 675-677.

Davies, S.M., Elmquist, M., Bergman, J., Wohlfarth, B. and Hammarlund, D., 2007. Cryptotephra sedimentation processes within two lacustrine sequences from west central Sweden. Holocene 17, 319-330.

Davies, S.M., Abbott, P.M., Pearce, N.J.G., Wastegård, S., Blockley, S.P.E., 2012. Integrating the INTIMATE records using tephrochronology: Rising to the challenge. Quaternary Science Reviews, $36,11-27$.

De Vivo, B., Rolandi, G., Gans, P.B., Calvert, A., Bohrson, W.A., Spera, F.J., Belkin, H.E., 2001. New constraints on the pyroclastic eruptive history of the Campanian volcanic Plain (Italy). Mineralogy and Petrology 73, 47-65. 
Dibble, H.L., Aldeias, V., Jacobs, Z., Olszewski, D.I., Rezek, Z., Lin, S.C., Alvarez-Fernández, E., Barshay-Szmidt, C.C., Hallett-Desguez, E., Reed, D., Reed, K., Richter, D., Steele, T.E., Skinner, A., Blackwell, B., Doronicheva, E., El-Hajraoui, M., 2013. On the industrial attributions of the Aterian and Mousterian of the Maghreb. Journal of Human Evolution 64, 194-210.

Douka, K., Jacobs, Z., Lane, C., Grün, R. Farr, L., Hunt, C., Inglis, R.H., Reynolds, T., Albert, P., Aubert, M., Cullen, V., Evan Hill, E., Kinsley, L., Roberts, R.G., Tomlinson, E.L., Wulf, S., Barker, G., 2014a. The chronostratigraphy of the Haua Fteah cave (Cyrenaica, northeast Libya). Journal of Human Evolution 66, 39-63.

Douka, K., Higham, T.F., Wood, R., Boscato, P., Gambassini, P., Karkanas, P., Peresani, M., Ronchitelli, A.M. 2014b. On the chronology of the Uluzzian. Journal of Human Evolution, 68, 113.

Geraads, D., Amani F., Ben-Ncer A., McPherron S.P, Raynal J.-P., Hublin J.-J., 2013. The rodents from the late middle Pleistocene hominid-bearing site of J'bel Irhoud, Morocco, and their chronological and paleoenvironmental implications. Quaternary Research 80 (3), 552-561.

Gertisser, R., Self, S., Gaspar, J. L., Kelley, S. P., Pimentel, A., Eikenberg, J., Barry, T. L., Pacheco, J. M., Queiroz, G., Vespa, M., 2010. Ignimbrite stratigraphy and chronology on Terceira Island, Azores. In: G. Groppelli, L. Viereck-Goette (Eds.), Geological Society of America Special Paper 464, 133-154.

Hamann, Y., Wulf, S., Ersoy, O., Ehrmann, W., Aydar, E., Schmiedl, G., 2010. First evidence of a distal early Holocee ash layer in the Eastern Mediterranean deep-sea sediments derived from the Anatolian volcanic province. Quaternary Research 73, 497-506.

Harvati, K., Hublin, J.-J., 2012. Morphological Continuity of the Face in the Late Middle and Late Pleistocene Hominins from Northwestern Africa: A 3D Geometric Morphometric Analysis. In: Hublin, J.-J., McPherron, S. (Eds.), Modern origins: A North African perspective. Springer, Dordrecht, pp. 179-188.

Hopkinson, T, Nowell, A., White, M., 2013. Life Histories, Metapopulation Ecology, and Innovation in the Acheulian. PaleoAnthropology 2013: 61-76. doi:10.4207/PA.2013.ART80

Hublin, J.-J., Tillier, A.-M., Tixier, J., 1987. L'humérus d'enfant moustérien (Homo 4) du Jebel Irhoud (Maroc) dans son contexte archéologique. Bulletin et Mémoires de la Société d'Anthropologie de Paris 4, série, XIV, 115-142.

Hublin, J.-J., Verna, C., Bailey, S., Smith, T., Olejniczak, A., Sbihi-Alaoui, F.Z., Zouak, M., 2012. Dental Evidence from the Aterian Human Populations of Morocco. In: Hublin, J.-J., McPherron, S. (Eds.), Modern origins: A North African perspective. Springer, Dordrecht, pp. 189-204.

Hunt, C., Davison, J., Inglis, R., Farr, L., Simpson, D., el-Rishi, H., Barker, G., 2010. Site formation processes in caves: the Holocene sediments of the Haua Fteah, Cyrenaica, Libya. Journal of Archaeological Science 37, 1600-1611.

Inglis, R.H., 2012. Human occupation and changing environments during the Middle to Later Stone Age: Soil micromorphology at the Haua Fteah, Libya. Ph.D. Dissertation, University of Cambridge. 
Jacobs, Z., Roberts, R.G., Nespoulet, R., El Hajraoui, M.A., Debénath, A., 2012. Single-grain OSL chronologies for Middle Palaeolithic deposits at El Mnasra and El Harhoura 2, Morocco: implications for Late Pleistocene human environment interactions along the Atlantic coast of northwest Africa. Journal of Human Evolution 62, 377-394.

Jochum, K.P., Nohl, U., Herwig, K., Lammel, E., Stoll, B., Hofmann, A.W., 2005. GeoReM: A new geochemical database for reference materials and isotopic standards. Geostandards and Geoanalytical Research 29, 333-338.

Jochum, K.P., Stoll, B., Herwig, K., Willbold, M., Hofmann, A.W., Amini, M., Aarburg, S., Abouchami, W., Hellebrand, E., Mocek, B., Raczek, I., Stracke, A., Alard, O., Bouman, C., Becker, S., Ducking, M., Bratz, H., Klemd, R., de Bruin, D., Canil, D., Cornell, D., de Hoog, C.J., Dalpe, C., Danyushevsky, L., Eisenhauer, A., Gao, Y.J., Snow, J.E., Goschopf, N., Gunther, D., Latkoczy, C., Guillong, M., Hauri, E.H., Hofer, H.E., Lahaye, Y., Horz, K., Jacob, D.E., Kassemann, S.A., Kent, A.J.R., Ludwig, T., Zack, T., Mason, P.R.D., Meixner, A., Rosner, M., Misawa, K.J., Nash, B.P., Pfander, J., Premo, W.R., Sun, W.D.D., Tiepolo, M., Vannucci, R., Vennemann, T., Wayne, D., Woodhead, J.D., 2006. MPI-DING reference glasses for in situ microanalysis: new reference values for element concentrations and isotope ratios. Geochemistry, Geophysics, Geosystems, 7.

Kieffer, G., 1979. L'activité de l'Etna pendant les dernières 20000 ans. C. R. Acad. Sci. D 288, 1023-1026.

Kindermann, K., Bubenzer, O., Van Peer, P., 2013. Geo-archaeological research on the Late Pleistocene of the Egyptian Eastern Desert: recent threats to the Sodmein Cave. Antiquity 87 (337), Antiquity Project Gallery.

Klein, R.G., 2009. The Human Career. Chicago University Press, Chicago, USA.

Lane, C.S., Cullen, V.L., White, D., Bramham-Law, C.W.F., Smith, V.C. 2014. Cryptotephra as a dating and correlation tool in archaeology. Journal of Archaeological Science 42, 42-50.

Lane, C.S., de Klerk, P., Cullen, V.L. 2012a. A tephrochronology for the Lateglacial vegetation record of Endinger Bruch, Vorpommern. Journal of Quaternary Science 27, 141-149.

Lane, C.S., Blockley, S.P.E., Mangerud, J., Smith, V.C., Lohne, Ø.S., Tomlinson, E.L., Matthews, I.P., Lotter, A.F., 2012b. Was the 12.1 ka Icelandic Vedde Ash one of a kind? Quaternary Science Reviews 33, 87-99.

Lee, S., Ramsey, C., Hardiman, M. 2013. Modeling the age of the Cape Riva (Y-2) tephra. Radiocarbon 55, 741-747.

Lowe, D.J., 2011. Tephrochronology and its application: A review. Quaternary Geochronology 6, $107-153$.

Lowe, J., Barton, N., Blockley, S., Bronk Ramsey, C., Cullen, V.L., Davies, W., Gamble, C., Grant, K., Hardiman, M., Housley, R., Lane, C.S., Lee, S., Lewis, M., MacLeod, A., Menzies, M., Müller, W., Pollard, M., Price, C., Roberts, A.P., Rohling, E.J., Satow, C., Smith, V.C., Stringer, C.B., Tomlinson, E.L., White, D., Albert, P., Arienzo, I., Barker, G., Bori_c, D., Carandente, A., Civetta, L., Ferrier, C., Guadelli, J., Karkanas, P., Koumouzelis, M., Müller, U.C., Orsi, G., Pross, J., Rosi, M., Shalamanov-Korobar, L., Sirakov, N., Tzedakis, P.C., 2012. Volcanic ash layers illuminate the resilience of Neanderthals and early modern humans to natural hazards. Proc. Natl. Acad. Sci. 109, $13532-13537$. 
Lubell, D., 2001. Late Pleistocene Early Holocene Maghreb, Africa. In: Peregrine, P.N., Ember, M. (Eds.), Encyclopedia of Prehistory, vol. 1. Kluwer, New York, pp. 129-149.

Martí, J., Geyer, A., Andujar, J., Teixidó, F., Costa, F., 2008. Assessing the potential for future explosive activity from Teide-Pico Viejo stratovolcanoes (Tenerife, Canary Islands). Journal of Volcanology and Geothermal Ressearch 178, 529-542.

Matthews, I.P., Birks, H.H., Bourne, A.J., Brooks, S.J., Lowe, J.J., Macleod, A., Pyne-O’Donnell, S.D.F., 2011. New age estimates and climatostratigraphic correlations for the Borrobol and Penifiler Tephras: evidence from Abernethy Forest, Scotland. Journal of Quaternary Science 26, 247-252.

McBrearty, S., Brooks, A.S., 2000. The revolution that wasn't: a new interpretation of the origin of modern human behavior. Journal of Human Evolution 39, 453-563.

McBurney, C.B.M., 1967. The Haua Fteah (Cyrenaica) and the Stone Age of the South-East Mediterranean. Cambridge University Press, Cambridge.

Mellars, P., 2006. Why did modern human populations disperse from Africa ca. 60,000 years ago? A new model. Proc. Nat. Acad. Sci. 103 (5), 9381-9386.

Mercier, N., Valladas, H., Froget, L., Joron, J-L., Vermeersch, P.M., Van Peer, P., Moeyersons, J., 1999. Thermoluminescence dating of a middle-palaeolithic occupation at Sodmein Cave, Red Sea Mountains (Egypt). Journal of Archaeological Science 26, 1339-1345.

Mercier, N., Wengler, L., Valladas, H., Joron, J.-L., Froget, L., Reyss, J.-L. 2007. The Rhafas Cave (Morocco): Chronology of the Mousterian and Aterian archaeological occupations and their implications for quaternary geochronology based on luminescence (TL/OSL) age determinations. Quaternary Geochronology 2, 309-313.

Mitchell, P.J., 2008. Developing the archaeology of marine isotope stage 3. S. Afr. Archaeol. Soc. Goodwin Ser. 10, 52-65.

Moeyersons, J., Vermeersch, P.M., Van Peer, P. 2002. Dry cave deposits and their palaeoenvironmental significance during the last $115 \mathrm{ka}$, Sodmein Cave, Red Sea Mountains, Egypt. Quat. Sci. Rev. 21, 837-51.

Morley, M.W., Woodward, J.C., 2011. The Campanian Ignimbrite (Y5) tephra at Crvena Stijena Rockshelter, Montenegro. Quaternary Research 75 (3), 683-696.

Müller, W., Shelley, M., Miller, P., Broude, S., 2009. Initial performance metrics of a new customdesigned ArF excimer LA-ICPMS system coupled to a two-volume laser-ablation cell. Journal of Analytical Atomic Spectrometry 24, 209-214.

Nami, M., Moser, J., 2010. La Grotte d'Ifri n’Ammar Ifri. Tome 2, Le Paléolithique Moyen. KAAK-Forschungen, Reichert Verlag, Wiesbaaden.

Queiroz, G., Pacheco, J.M., Gaspar, J.L., Aspinall, W.P., Guest, J.E., Ferreira, T., 2008. The last 5000 years of activity at Sete Cidades volcano (SÃ£o Miguel Island, Azores): Implications for hazard assessment. Journal of Volcanology and Geothermal Research 178, 562-573. 
Payne, R., Gehrels, M., 2010. The formation of tephra layers in peatlands: an experimental approach. Catena 81, 12-23.

Pollard, A. M., Blockley, S. P. E., Ward, K. R. 2003. Chemical alteration of tephra in the depositional environment: theoretical stability modelling. Journal of Quaternary Science 18, 385394.

Rasmussen, S.O., Andersen, K.K., Svensson, A.M., Steffensen, J.P., Vinther, B.M., Clausen, H.B., Siggaard-Andersen, M.L., Johnsen, S.J., Larsen, L.B., Dahl-Jensen, D., Bigler, M., Röthlisberger, R., Fischer, H., Goto-Azuma, K., Hansson, M.E., Ruth, U., 2006. A new Greenland ice core chronology for the last glacial termination. Journal of Geophysical Research D: Atmospheres 111, $18-28$.

Raynal J.-P., Sbihi-Alaoui F.-Z., Mohib A., 2010. Bilan des recherches récentes sur le Paléolithique de Casablanca (Maroc), Les Nouvelles de l'Archéologie 120-121, 102-109.

Reimer, P.J., Bard, E., Bayliss, A., Beck, J.W., Blackwell, P.G., Bronk Ramsey, C., Buck, C.E., Cheng, H., Edwards, R.L., Friedrich, M., Grootes, P.M., Guilderson, T.P., Haflidason, H., Hajdas, I., Hatté, C., Heaton, T.J., Hoffmann, D.L., Hogg, A.G., Hughen, K.A., Kaiser, K.F., Kromer, B., Manning, S.W., Niu, M., Reimer, R.W., Richards, D.A., Scott, E.M., Southon, J.R., Staff, R.A., Turney, C.S.M., van der Plicht, J., 2013. IntCal13 and Marine13 radiocarbon age calibration curves 0-50,000 years cal BP. Radiocarbon 55 (4), 1869-1887.

Reynolds, T., 2013. The Middle Palaeolithic of Cyrenaica: is there an Aterian at the Haua Fteah and does it matter? Quaternary International 300, 171-181.

Reygasse, M., 1919-1920. Etudes de Palethnologie Maghrébine (Nouvelle série). Rec. Not. Mém. Soc. Archeol. Constantine LIII.

Reyss, J.-L., Valladas, H., Mercier, N., Froget, L., Joron, J.-L., 2007. Applications des methods de la thermoluminescence et des déséquilibres dans la famille de l'uranium au gisement archéologique. In: Roset, J.-P., Harbi-Riahi, M. (Eds.), El Akarit: Un site archéologique du Paléolithique Moyen dans le Sud de la Tunisie. Editions Recherches sur les Civilisations, Paris, pp. 357-364.

Richter, D., Moser, J., Nami, M., 2012. New data from the site of Ifri n'Ammar (Morocco) and some remarks on the chronometric status of the Middle Paleolithic in the Maghreb. In: Hublin, J.-J., McPherron, S. (Eds.), Modern origins: A North African perspective. Springer, Dordrecht, pp. 6178.

Roset, J.-P., Harbi-Riahi, M. (Eds.), 2007. El Akarit: Un site archéologique du Paléolithique Moyen dans le Sud de la Tunisie. Editions Recherches sur les Civilisations, Paris.

Ruhlmann, A., 1951. La grotte préhistorique de Dar es-Soltan. In: Collection Hésperis 11. Institut des Hautes Etudes Marocaines, Larose, Paris, pp. 1-210.

Sarikaya, M.A., Zreda, M., Desilets, D., Ciner, A., Sen, E., 2006. Correcting for nucleogenic 36Cl in cosmogenic $36 \mathrm{Cl}$ dating of volcanic rocks from Erciyes volcano, Central Turkey. American Geophysical Union Conference, San Francisco, USA 11-15 December 2006, V21A-0553.

Sarikaya, M.A., Zreda, M., Ciner, A., 2009. Glaciations and palaeoclimate of Mount Erciyes, central Turkey, since the Last Glacial Maximum, inferred from $36 \mathrm{Cl}$ cosmogenic dating and glacier modelling. Quat. Sci. Rev. 28, 2326-2341. 
Scerri, E., 2013. The Aterian and its place in the North African Middle Stone Age. Quaternary International 300, 111-130.

Schiano, P., Clocchiatti, R., Ottolini, L., Busa', T., 2001. Transition of Mount Etna lavas from a mantle-plume to an island-arc magmatic source. Nature 412 (30), 900-904.

Schiano, P., Clocchiatti, R., Ottolini, L., Sbrana, A., 2004. The relationship between potassic, calcalkaline and Na-alkaline magmatism in South Italy volcanoes: A melt inclusion approach. Earth and Planetary Science Letters 220, 121-137.

Schmitt, A., Danisik, M., Evans, N., Siebel, W., Kiemele, E., Aydin, F., Harvey, J., 2011. Acigol rhyolite field, Central Anatolia (part 1): high-resolution dating of eruption episodes and zircon growth rates. Contributions to Mineralogy and Petrology 162 (6), 1215-1231.

Schwenninger, J.-L., Collcutt, S.N., Barton, N., Bouzouggar, A., Clark- Balzan, L., El Hajraoui, M.A., Nespoulet, R., Debénath, A., 2010. A new luminescence chronology for Aterian cave sites on the Atlantic coast of Morocco. In: Garcea, E.A. (Ed.), South-Eastern Mediterranean Peoples between 130,000 and 10,000 Years Ago. Oxbow Books, Oxford, pp. 18-36.

Smith, T. M., Tafforeau, P. T., Reid, D. J., Grün, R., Eggins, S., Boutakiout, M., Hublin, J.-J., 2007. Earliest evidence of modern human life history in North African early Homo sapiens. Proceedings of the National Academy of Sciences of the USA 104, 6128-6133.

Stringer, C., 2012. What makes a modern human? Nature 485, 33-35.

Stringer, C.B., Barton, R.N.E., 2008. Putting North Africa on the map of modern human origins. Evolutionary Anthropology 17, 5-7.

Tixier, J., 1958-1959. Les pièces pédonculés de l’Atérien. Libyca VI-VII, 127-158.

Tomlinson, E.L., Thordarson, T., Müller, W., Thirlwall, M., Menzies, M.A., 2010. Microanalysis of tephra by LA-ICP-MS - Strategies, advantages and limitations assessed using the Thorsmörk ignimbrite (Southern Iceland). Chemical Geology 279, 73-89.

Tomlinson., E.L., Smith, V.C., Albert, P.A., Aydar, R., Civetta, L., Cioni, R., Çubukçu, E., Gertisser, R., Isaia, R., Menzies, M., Orsi, G., Rosi, M., Zanchetta, G. Determining the source of $<100 \mathrm{ka}$ tephra layers in the central and eastern Mediterranean. Quaternary Science Reviews, this issue.

Turney, C.S.M., 1998. Extraction of rhyolitic component of Vedde microtephra from minerogenic lake sediments. Journal of Paleolimnology 19, 199-206.

Van Peer, P., 2004. Did Middle Stone Age moderns of sub-saharan african descent trigger an Upper Paleolithic revolution in the lower Nile Valley? Anthropologie (Brno) 42, 215-225.

Van Peer, P., Technological Systems, Population Dynamics and Historical Process in the MSA of Northern Africa. In: Jones S., Stewart B. (Eds.), Africa from MIS 6-2: Population Dynamics and Paleoenvironments, Springer, in press.

Van Peer, P., Vermeersch, P.M., 2007. The place of Northeast Africa in the early history of modern humans: new data and interpretations on the Middle Stone Age. In: Mellars, P., Boyle, K., Bar- 
Accepted for publication in Quaternary Science Reviews on 05/09/2014

Yosef, O., Stringer, C. (Eds.), Rethinking the Human Revolution. Macdonald Institute Monographs, Cambridge, pp. 187-198.

Vermeersch, P.M., Van Peer, P., 2012. Le Belgian Middle Egypt Prehistoric Project de la Katholieke Universiteit Leuven. In: Bavay, L., Bruwier, M.-C., Claes, W., De Strooper, I. (Eds.), Ceci n'est pas une pyramide... Un siècle de recherché archéologique belge en Egypte. Peeters, Leuven, pp. 115-25.

Vermeersch, P.M., Van Peer, P.M., Moeyersons, J., Van Neer, W., 1994. Sodmein Cave site, Red Sea Mountains (Egypt). Sahara 6, 31-40.

Villa, P., Soriano, S., Tsanova, T., Deganof, I., Higham, T.F.G., d'Errico, F., Backwell, L., Lucejko, J.J., Colombini, M.P., Beaumont, P.B., 2012. Border Cave and the beginning of the Later Stone Age in South Africa. Proc. Natl. Acad. Sci. 109, 13208-13213.

Wengler, L., 1993. Formations quaternaires et cultures préhistoriques au Maroc oriental. Thèse de Doctorat d'État, l'Université Bordeaux I.

Wulf, S., Kraml, M., Brauer, A., Keller, J., Negendank, J.F.W., 2004. Tephrochronology of the 100 ka lacustrine sediment record of Lago Grande di Monticchio (southern Italy). Quaternary International 122, 7-30.

Wulf, S., Brauer, A., Mingram, J., Zolitschka, B., Negendank, J.F.W., 2007. Distal tephras in the sediments of Monticchio maar lakes. In: Principe, C. (Ed.), Geologia del Monte Vulture. Boll. Soc. Geol. Ital., 105-122. 